\title{
Messy Mental Markers: Inferring Scienter from Core Operations in Securities Fraud Litigation
}

\author{
MICHAEL J. KAUFMAN ${ }^{*} \&$ JOHN M. WUNDERLICH ${ }^{\dagger}$
}

In all aspects of the law, proving that a defendant acted with a particular mental state is messy. Direct evidence of the complex inner workings of the mind is virtually nonexistent. Accordingly, litigants, juries, and judges often must infer a mental state from external "markers," such as circumstantial evidence.

The search for mental markers is particularly messy in the area of securities fraud litigation. To obtain remedies for violations of the federal securities laws, victims typically must plead and prove that the perpetrators acted with "scienter." As variously defined by the Supreme Court, scienter is a mental state that embraces an intent to deceive, but also includes some degree of recklessness. To make matters more complicated, the Private Securities Litigation Reform Act requires victims of securities fraud to allege with particularity facts that give rise to a "strong inference of scienter." In Tellabs, Inc. v. Makor Issues \& Rights, Ltd., 551 U.S. 308 (2007), the Supreme Court interpreted this requirement, holding that a securities fraud complaint is viable only if "a reasonable person would deem the inference of scienter cogent and at least as compelling as any opposing inference one could draw from the facts alleged." Since Tellabs, the federal courts have been mired in threshold litigation about the sufficiency of scienter allegations, often demanding an unsuitable degree of particularity and reading Tellabs to invite a laborious evidentiary weighing process at the initial pleading stage.

In this Article, we attempt to lend clarity and precision to one key aspect of this judicial attempt to evaluate markers of scienter: the core operations inference. We demonstrate that the federal courts should recognize that the inference of scienter is strong where senior officers make misleading statements regarding matters within their company's core operations. An allegation that a senior officer made a material misrepresentation about matters within the organization's core operations is a remarkably clear marker of intentional or reckless behavior. We also show that the core operations inference is consistent with the design of the federal securities laws, and with the Supreme Court's most recent securities fraud decisions, properly understood. Equipped

${ }^{*}$ Professor of Law and Associate Dean for Academic Affairs at Loyola University Chicago School of Law.

$\dagger$ Institute Scholar, Institute for Investor Protection, Loyola University Chicago School of Law; former staff law clerk for the U.S. Court of Appeals for the Seventh Circuit; J.D., Loyola University Chicago School of Law, 2009.

Special thanks to Professor Barbara Black of the University of Cincinnati College of Law, and Jason S. Cowart, Marc I. Gross, and Stanley M. Grossman of Pomerantz Haudek Grossman \& Gross LLP, for their helpful comments and suggestions. Thanks also to the editorial staff at the Ohio State Law Journal for their tremendous efforts. Additionally, the ideas expressed in this Article greatly benefited from the conversations and talks at the "Access to Justice" Symposium sponsored by the Institute for Law and Economic Policy, and particularly from Professors Jim Cox, Donald C. Langevoort, and Geoffrey P. Miller. 
with the core operations inference, therefore, federal courts should be able to resolve efficiently a significant part of litigation over the issue of scienter in securities fraud cases.

\section{TABLE OF CONTENTS}

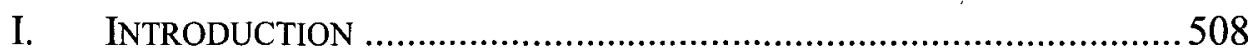

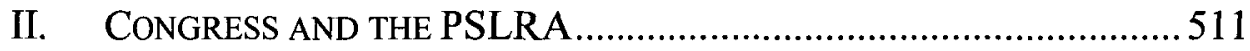

A. Pleading Securities Fraud with Particularity .........................512

B. Pleading a Strong Inference of Scienter and Recklessness ....513

III. THE CORE OPERATIONS INFERENCE OF SCIENTER: PLEADING

RECKLESSNESS THROUGH MATERIALITY .....................................516

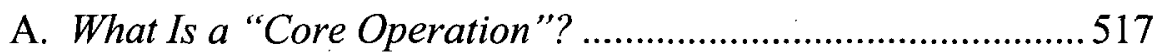

B. Who Should Have Knowledge of Core Operations? ...............519

C. A Note About the Core Operations Inference, Summary Judgment, and Trial .............................................................525

IV. THE CURRENT SLIDING-SCALE APPROACH TO THE CORE

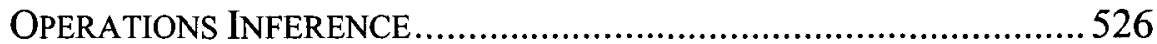

A. The More Significant the Fact Is to the Company, the More Indicative of Scienter and the Less the Need for Particularized Allegations...

B. The Less Significant the Fact Is to the Company, the Less Indicative of Scienter and the More the Need for Particularized Allegations ......................................................... 533

V. THE SUPREME COURT AND THE CORE OPERATIONS INFERENCE ....534

A. Senior Management as Culpable Actors ...............................535

B. Materiality as a Basis to Infer Scienter ..................................536

C. Subsuming the Particularity Requirement .............................538

VI. CONCLUSION. .540

\section{INTRODUCTION}

Discovering and proving any mental state is messy. We cannot read minds, so, without an admission, direct evidence of the complex inner workings of the mind is virtually nonexistent. Accordingly, litigants, judges, and juries often must infer a mental state from external mental "markers," or circumstantial evidence.

The search for mental markers is particularly messy in the area of securities fraud litigation, where a defendant's state of mind is paramount. Only defendants who act with scienter-an intent to deceive, manipulate, or defraud ${ }^{1}$ - can be held liable under Section 10(b) of the Securities Exchange

${ }^{1}$ Ernst \& Ernst v. Hochfelder, 425 U.S. 185, 193, 194 n.12 (1975). 
Act of 1934 and Rule $10 \mathrm{~b}-5,{ }^{2}$ the most potent of the antifraud remedies. And under the Private Securities Litigation Reform Act of 1995 (PSLRA), plaintiffs must allege with particularity "a strong inference" of scienter. ${ }^{3}$ In Tellabs, Inc. v. Makor Issues \& Rights, Ltd., the Supreme Court interpreted this requirement, holding that a securities fraud complaint is viable only if "a reasonable person would deem the inference of scienter cogent and at least compelling as any opposing inference one could draw from the facts alleged." federal courts have been mired in threshold litigation about the particularity and sufficiency of scienter allegations, often reading Tellabs to invite a laborious, evidentiary weighing process at the initial pleading stage.

This Article tries to lend clarity and precision to one specific but critical aspect of this judicial attempt to evaluate markers of scienter: inferring scienter from misleading statements about the company's core operations. We demonstrate that the federal courts should begin to recognize that the inference of scienter is particularly strong where senior officers make misleading statements regarding matters within their company's "core operations," even without particularized allegations. Allegations that a senior officer made a material misrepresentation about matters within the organization's core operations are a remarkably clear marker of intentional or reckless behavior. We also show that the core operations inference is consistent with the design of the federal securities laws and with the Supreme Court's most recent securities fraud decisions, properly understood. Equipped with the core operations inference, therefore, federal courts should be able to efficiently resolve a significant part of litigation over the issue of scienter in securities fraud cases.

Judicial recognition of the core operations inference takes on renewed significance after Tellabs because the doctrine prevents district judges from abusing their newfound discretion in weighing inferences and discounting culpable ones. In Tellabs, the Supreme Court held that a securities fraud complaint should survive dismissal if "a reasonable person would deem the inference of scienter cogent and at least as compelling as any opposing

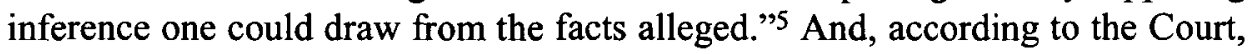

${ }^{2}$ Section 10(b) of the Securities Exchange Act of 1934 and Rule 10b-5 prohibit any company or person from making any untrue statement of a material fact or from omitting a material fact necessary in order to make the statements made in the light of the circumstances under which they were made, not misleading. 15 U.S.C. $\$ 78 \mathrm{j}$ (b) (2006); 17 C.F.R. $\S 10 b-5$ (b) (2011).

${ }_{1} 15$ U.S.C. $\$ 78 \mathrm{u}-4$ (b)(2). The other elements of a securities fraud claim under Section 10(b) and Rule 10b-5 include: (1) that the defendant made a material misrepresentation or omission (materiality), (2) that the material misrepresentation or omission was made in connection with the purchase or sale of a security (in connection with), (3) that the plaintiff relied on the material misrepresentation (reliance), (4) that the plaintiff suffered an economic loss as a result (economic loss), and (5) that the material misrepresentation actually caused the loss (loss causation). See, e.g., Dura Pharm., Inc. v. Broudo, 544 U.S. 336, 341-42 (2005).

4551 U.S. 308, 324 (2007).

5 Id. 
to determine whether the inference is strong, district judges should weigh plausible culpable and nonculpable inferences. ${ }^{6}$ But this weighing implicitly leaves district judges considerable discretion to determine which inferences are reasonable, which inferences to discount, and how the strength of any given inference compares to another. The problem is that district judges might discount allegations of scienter as less likely than virtually any other nonculpable mental state, including negligence, ignorance, and even indifference. $^{7}$

Without judicial recognition of the core operations inference, courts may discount circumstantial allegations that would amount to recklessness, or worse, twist the fact that the allegation concerns the core operations of the company against plaintiffs. Cozzarelli v. Inspire Pharmaceuticals Inc. ${ }^{8}$ is such an example. There, the plaintiffs alleged that Inspire, a manufacturer of an experimental drug (and "one of the company's flagship products") to treat dryeye disease, misstated the results of its clinical trials. The Fourth Circuit held that the plaintiffs did not allege a strong inference of scienter because the drug involved in the misstatements was so essential to the company's success that "[i]t is improbable that Inspire would stake its existence on a drug and a clinical trial that the company thought was doomed to failure. Plaintiffs' inference of fraud ... is thus not even plausible, much less convincing." ${ }^{9}$ But, as this Article shows, the core operations inference is plausible and convincing. ${ }^{10}$

Part II of this Article revisits the PSLRA's dual-pleading requirement that plaintiffs must plead both (1) facts, including those concerning a defendant's state of mind, with particularity; and (2) a strong inference of scienter. Part III explains that a proper understanding of the core operations inference means that if senior management makes misleading statements pertaining to facts that are material to investors, then the inference that the defendant acted recklessly is

${ }^{6} I d$.

${ }^{7}$ See Michael J. Kaufman \& John M. Wunderlich, The Judicial Access Barriers to Remedies for Securities Fraud, 75 LAW \& CONTEMP. ProBS. 55, 56-58 (2012). We do not mean to suggest that the application of Tellabs always results in a judgment against plaintiffs. Some examples of the opposite result are discussed in this Article. See, e.g., N.M. State Inv. Council v. Ernst \& Young LLP, 641 F.3d 1089, 1095 (9th Cir. 2011); Schleicher v. Wendt, 529 F. Supp. 2d 959, 961 (S.D. Ind. 2007).

8549 F.3d 618 (4th Cir. 2008).

${ }^{9}$ Id. at 627.

${ }^{10}$ Although the doctrine is helpful to plaintiffs, elsewhere we have questioned whether the doctrine could be used offensively to trigger the statute of limitations. See Michael J. Kaufman \& John M. Wunderlich, Toward a Just Measure of Repose: The Statute of Limitations in Securities Fraud, 52 WM. \& MARY L. REV. 1547, 1579-81 (2011). Moreover, adopting the core operations inference may just shift the dispute from whether the facts suggest scienter to whether the facts actually relate to the company's core operations. See, e.g., In re eSpeed, Inc. Sec. Litig., 457 F. Supp. 2d 266, 294 n.210 (S.D.N.Y. 2006) (collecting cases that declined to apply the core operations inference when the plaintiffs did not sufficiently allege facts suggesting that alleged fraud was at the core of the company's operations). 
cogent and compelling, even absent particularized allegations. Part IV shows that the federal courts have attempted to accommodate the core operations inference by adopting a sliding-scale approach: the more material the misrepresentation, then the more likely a court will infer scienter absent particularized allegations of knowledge.

Part V argues that the Supreme Court has implicitly endorsed the core operations inference. To show that the Court has endorsed this inference, this Article attempts to refine the doctrine and harmonize the seemingly conflicting treatment of the core operations inference among the federal appellate courts. Part $\mathrm{V}$ begins by showing that the inference is not inconsistent with Court precedent, even when the Court is restricting the scope of liability under Rule 10b-5. In Janus Capital Group, Inc. v. First Derivative Traders ${ }^{11}$ and Stoneridge Investment Partners, LLC v. Scientific-Atlanta, Inc., ${ }^{12}$ the Court recognized that, although defendants have no affirmative duty to speak, when someone makes a publicly misleading statement, he can be held liable under Rule 10b-5. Second, Part V shows that in Merck \& Co. v. Reynolds ${ }^{13}$ and Matrixx Initiatives, Inc. v. Siracusano, ${ }^{14}$ the Court acknowledged that a strong inference of scienter exists where a defendant makes a misleading statement about facts that are so material to the company and investors such that it would be absurd to suggest that the defendant did not know about them. And last, in Tellabs, Inc. v. Makor Issues \& Rights, Ltd., ${ }^{15}$ the Court softened the PSLRA's particularity requirement to a single factor in a holistic scienter analysis so that the lack of particularized allegations will not defeat an inference of scienter, even one generated by the core operations inference. Part VI concludes that judicial recognition of the core operations inference should help injured investors with merited claims survive a motion to dismiss.

\section{CONGRESS AND THE PSLRA}

In 1995, Congress perceived that the litigation and settlement of a securities fraud claim became unmoored from the merits. ${ }^{16}$ To curb what Congress perceived as abusive filings, Congress enacted the PSLRA, which demanded that plaintiffs plead with particularity a strong inference that the defendant acted

11131 S. Ct. 2296, 2301 (2011).

12552 U.S. 148 (2008).

13130 S. Ct. 1784 (2010).

14131 S. Ct. 1309,1313 (2011).

15551 U.S. $308,326(2007)$.

16 The premise underlying the PSLRA-that the merits of a claim do not matter when a company determines whether to settle-has been thoroughly critiqued. See, e.g., Joel Seligman, The Merits Do Matter: A Comment on Professor Grundfest's "Disimplifying Private Rights of Action Under the Federal Securities Laws: The Commission's Authority," 108 HARV. L. REV. 438, 444-49 (1994); Elliott J. Weiss \& John S. Beckerman, Let the Money Do the Monitoring: How Institutional Investors Can Reduce Agency Costs in Securities Class Actions, 104 YALE L.J. 2053, 2080-84 (1995). 
with scienter. ${ }^{17}$ The PSLRA's pleading requirement has two components: (1) that the plaintiff alleges facts with particularity; and (2) that the plaintiff alleges a strong inference of scienter, also with particularity. ${ }^{18}$ The federal appellate courts have long treated these as distinct. ${ }^{19}$ Both components address the plaintiff's pleading burden, but in different and significant respects.

\section{A. Pleading Securities Fraud with Particularity}

The PSLRA requires plaintiffs to allege with particularity the defendant's state of mind and each statement alleged to have been misleading, why it is misleading, and if made on information and belief, all facts on which that belief is formed. ${ }^{20}$ The particularity requirement embodies Congress's judgment that Rule 9(b) governs securities fraud claims. ${ }^{21}$ But unlike Rule 9(b), which allows plaintiffs to allege a mental state generally, under the PSLRA, plaintiffs must allege the defendant's mental state with particularity. ${ }^{22}$ The PSLRA requires plaintiffs to allege the "who, what, where, why, and when" surrounding the fraud and the defendant's state of mind. 23

The particularity requirement serves three purposes: first, it is believed that particularized allegations make the truth of these allegations more probable. ${ }^{24}$ Second, to allege facts with the requisite detail, plaintiffs must undertake

${ }^{17}$ S. REP. No. 104-98, at 15 (1995), as reprinted in 1995 U.S.C.C.A.N. 679, 694; see also 15 U.S.C. $\S 78 \mathrm{u}-4(\mathrm{~b})(1)-(2)(2006)$.

1815 U.S.C. $\$ 78 \mathrm{u}-4(\mathrm{~b})(1)-(2)$. Professor Michael Perino observes that the PSLRA has three distinct requirements: (1) specificity; (2) particularity; and (3) a strong inference. Michael A. Perino, Did the Private Securities Litigation Reform Act Work?, 2003 ILL. L. REV. 913,925.

${ }^{19}$ See, e.g., La. Sch. Emps. Ret. Sys. v. Ernst \& Young, LLP, 622 F.3d 471, 478 (6th Cir. 2010); In re GlenFed, Inc. Sec. Litig., 42 F.3d 1541, 1546 (9th Cir. 1994) (en banc); Holmes v. Baker, 166 F. Supp. 2d 1362, 1376 (S.D. Fla. 2001).

2015 U.S.C. $\S 78 \mathrm{u}-4(\mathrm{~b})(1)-(2)$.

${ }^{21}$ See, e.g., Institutional Investors Grp. v. Avaya, Inc., 564 F.3d 242, 253 (3d Cir. 2009); Rubke v. Capitol Bancorp Ltd., 551 F.3d 1156, 1165 (9th Cir. 2009); Miss. Pub. Emps. Ret. Sys. v. Bos. Scientific Corp., 523 F.3d 75, 85 n.5 (1st Cir. 2008); Cent. Laborer's Pension Fund v. Integrated Elec. Servs. Inc., 497 F.3d 546, 550 (5th Cir. 2007).

${ }^{2}$ Compare FED. R. CIV. P. 9(b), with 15 U.S.C. $§ ~ 78 \mathrm{u}-4(\mathrm{~b})(1)$. See also Zucco Partners, LLC v. Digimarc Corp., 552 F.3d 981, 990 (9th Cir. 2009); Mizzaro v. Home Depot, Inc., 544 F.3d 1230, 1237-38 (11th Cir. 2008). Originally, securities fraud cases were assessed under Federal Rule of Civil Procedure 9(b), which governed all civil allegations of fraud. See, e.g., Mills v. Polar Molecular Corp., 12 F.3d 1170, 1175 (2d Cir. 1993).

${ }^{23}$ See, e.g., Institutional Investors Grp., 564 F.3d at 253 (explaining the particularity requirement under the PSLRA); DiLeo v. Emst \& Young, 901 F.2d 624, 627 (2d Cir. 1990) (explaining the particularity requirement under Rule 9(b)).

${ }^{24}$ See Geoffrey P. Miller, Pleading After Tellabs, 2009 WIS. L. REV. 507, 516. There is some reason to be skeptical of this claim, however, as Professor Reinert has found that traditional notice pleading is no better than heightened (or "plausibility") pleading in separating the wheat from the chaff. Alexander A. Reinert, The Costs of Heightened Pleading, 86 IND. L.J. 119, 125-26, 159 (2011). 
adequate investigation to verify the soundness of their claim before filing a complaint. This is no easy task as discovery is stayed in securities litigation pending any motion to dismiss. ${ }^{25}$ Thus, the particularity requirement encourages investors to be diligent in protecting against fraud. ${ }^{26}$ Third, particularized pleading ensures that plaintiffs seek redress for a known wrong rather than use a lawsuit as pretext to discover an unknown wrong. ${ }^{27}$ Ergo, the particularity requirement protects defendants from unnecessary harm to their reputation and, for public firms, protects them from unnecessary harm to their stock price. The federal appellate courts do not hesitate to dismiss a securities fraud complaint that does not allege facts with the requisite particularity. ${ }^{28}$

\section{B. Pleading a Strong Inference of Scienter and Recklessness}

The PSLRA also requires plaintiffs to allege a "strong inference" of scienter. ${ }^{29}$ This requirement serves one of the aims of the securities laws and the antifraud remedies: deterrence. ${ }^{30}$ Optimal deterrence is probably best achieved by influencing the incentives of culpable persons and firms, i.e., those who act with scienter. To that end, the PSLRA requires plaintiffs to allege "a strong inference" of scienter, ${ }^{31}$ the culpable mental state of the defendant.

First, we turn to the "strong inference." To discuss a "strong inference," we need to define it, which is no easy task. A "strong inference" is a messy, vague concept. To start, an "inference" is a conclusion reached by considering other facts and deducing a logical conclusion from those facts. ${ }^{32} \mathrm{Next}$, this inference must be "strong." The Supreme Court in Tellabs tried to provide guidance on when an inference will be "strong": The facts alleged when taken as true and assessed collectively generate an inference that the defendant acted with

2515 U.S.C. $\S 78 \mathrm{u}-4(\mathrm{~b})(3)$.

${ }^{26}$ See Kaufman \& Wunderlich, supra note 10 , at 1591-93 (stating that marshaling allegations sufficient to meet the PSLRA's heightened pleading requirement takes time, and thus plaintiffs are prompted to investigate early).

${ }^{27}$ When Congress implemented the stay of discovery in the PSLRA, Congress specifically sought to discourage the practice of filing a lawsuit and then using discovery to uncover a sustainable claim. See S. REP. No. 104-98, at 14 (1995), as reprinted in 1995 U.S.C.C.A.N. $679,693$.

${ }^{28}$ See 5 ALAN R. BROMBERG \& LEWIS D. LOWENFELS, BROMBERG \& LOWENFELS ON SECURITIES FRAUD \& COMMODITIES FRAUD $\S 10: 83$ (2d ed. 2010) (collecting cases).

2915 U.S.C. $\S 78 \mathrm{u}-4(\mathrm{~b})(2)$.

${ }^{30}$ For a discussion of the securities laws' goal of deterrence and a proposal for improvement, see Amanda M. Rose, Reforming Securities Litigation Reform: Restructuring the Relationship Between Public and Private Enforcement of Rule 10b-5, 108 COLUM. L. REV. 1301, 1307-25 (2008). Recent scholarship on the effects of SEC and class action enforcement of the securities laws finds that these mechanisms significantly deter aggressive financial reporting behavior. See generally Jared Jennings et al., The Deterrent Effects of SEC Enforcement and Class Action Litigation (Dec. 2011) (unpublished manuscript), available at $\mathrm{http}: / / \mathrm{ssrn}$.com/abstract $=1868578$.

31 15 U.S.C. $\$ 78 \mathrm{u}-4(\mathrm{~b})(2)$.

32 BLACK's LAW DiCTIONARY 666 (9th ed. 2009). 
scienter that is at least as likely as an inference that the defendant did not. ${ }^{33}$ Yet weighing inferences is difficult, and the strength of any one inference is likely in the eye of the beholder. ${ }^{34}$

Second, we must define "scienter." "Scienter" embraces intent to deceive, manipulate, or defraud. ${ }^{35}$ According to every federal court of appeals, "intent" encompasses some form of recklessness as well. ${ }^{36}$ Recklessness is defined as:

[A] highly unreasonable omission, involving not merely simple, or even inexcusable negligence, but an extreme departure from the standards of ordinary care, and which presents a danger of misleading buyers or sellers that is either known to the defendant or is so obvious that the actor must have been aware of it. ${ }^{37}$

Although the federal appellate courts have couched their recklessness standards differently (i.e., "deliberate recklessness,"38 "conscious recklessness,"39 "severe recklessness,"40 "extreme recklessness,"41 or

${ }^{33}$ Tellabs, Inc. v. Makor Issues \& Rights, Ltd., 551 U.S. 308, 322-24 (2007).

${ }^{34}$ See John M. Wunderlich, Note, Tellabs v. Makor Issues \& Rights, Ltd.: The Weighing Game, 39 LoY. U. CHI. L.J. 613, 649-51 (2008); see also Devona L. Wells, Case Note, Why Plaintiffs Should Learn to Love the Strong-Inference Standard for Pleading a Securities Fraud Claim - Tellabs v. Makor Issues \& Rights, Ltd., 36 WM. MITCHELL L. REV. 1364,1381 (2010) ("Tellabs reinforced the deference given to a judge's subjective views on the severity of wrongdoing in fraud cases and did not, therefore, materially change the way judges handle securities fraud cases.").

${ }^{35}$ Ernst \& Emst v. Hochfelder, 425 U.S. 185, 193-94 n. 12 (1975).

${ }^{36}$ Before the PSLRA, the circuits recognized that recklessness was sufficient to trigger liability. See, e.g., McLean v. Alexander, 599 F.2d 1190, 1197 (3d Cir. 1979); Nelson v. Serwold, 576 F.2d 1332, 1337 (9th Cir. 1978); Wright v. Heizer Corp., 560 F.2d 236, 251 (7th Cir. 1977); First Va. Bankshares v. Benson, 559 F.2d 1307, 1314 (5th Cir. 1977). After the PSLRA and Tellabs, the circuits still recognized that recklessness is sufficient to trigger liability under Rule 10b-5. See, e.g., City of Dearborn Heights Act 345 Police \& Fire Ret. Sys. v. Waters Corp., 632 F.3d 751, 757 (1st Cir. 2011); Dronsejko v. Thornton, 632 F.3d 658, 665 (10th Cir. 2011); La. Sch. Emps. Ret. Sys. v. Ernst \& Young, LLP, 622 F.3d 471, 479 (6th Cir. 2010); Detroit Gen. Ret. Sys. v. Medtronic, Inc., 621 F.3d 800, 808 (8th Cir. 2010); Edward J. Goodman Life Income Trust v. Jabil Circuit, Inc., 594 F.3d 783, 790 (11 th Cir. 2010); Siracusano v. Matrixx Initiatives, Inc., 585 F.3d 1167, 1180 (9th Cir. 2009), aff'd, 131 S. Ct. 1309 (2011); Liberty Prop. Trust v. Republic Props. Corp., 577 F.3d 335, 342 (D.C. Cir. 2009); Matrix Capital Mgmt. Fund, LP v. BearingPoint, Inc., 576 F.3d 172, 181 (4th Cir. 2009); S. Cherry St., LLC v. Hennessee Grp. LLC, 573 F.3d 98, 109 (2d Cir. 2009); Lormand v. US Unwired, Inc., 565 F.3d 228, 251 (5th Cir. 2009); Institutional Investors Grp. v. Avaya, Inc., 564 F.3d 242, 252 (3d Cir. 2009); Pugh v. Tribune Co., 521 F.3d 686, 693 (7th Cir. 2008).

${ }^{37}$ Sundstrand Corp. v. Sun Chem. Corp., 553 F.2d 1033, 1045-47 (7th Cir. 1977); see also RESTATEMENT (SECOND) OF TORTS $\S 500$ (1965). The line between negligence, recklessness, and intent is not always clear, however. See generally Geoffrey Christopher Rapp, The Wreckage of Recklessness, 86 WASH. U. L. REV. 111 (2008).

38 See, e.g., In re Silicon Graphics Inc. Sec. Litig., 183 F.3d 970, 979 (9th Cir. 1999).

${ }^{39}$ See, e.g., Novak v. Kasaks, 216 F.3d 300, 312 (2d Cir. 2000). 
"conscious disregard"42), Professor Ann Morales Olazábal shows that the application among the circuit courts of appeals tends to converge on whether the defendant's misstatements or omissions are an extreme departure from the standards of ordinary care presenting a danger of misleading investors that is either known to the defendant or so obvious that the actor must have been aware of it. 43 Thus, under one prong, the objective obviousness of the danger of misleading statements is alone sufficient to infer scienter, even if the defendant does not actually appreciate that risk. ${ }^{44}$ The federal appellate courts have long accepted this standard for the state of mind required for liability, 45 and in fact several standard jury instructions have embraced enabling the factfinder to infer the defendant's scienter from the objective obviousness of the danger of misleading statements. 46

The Supreme Court has explicitly left open the question whether recklessness suffices to meet the scienter requirement of Rule $10 \mathrm{~b}-5$, but the Court has not suggested restiveness with the conclusion that some form of recklessness is enough. ${ }^{47}$ The conclusion that recklessness is sufficient to

${ }^{40}$ See, e.g., Ottmann v. Hanger Orthopedic Grp., Inc., 353 F.3d 338, 344 (4th Cir. 2003); Nathenson v. Zonagen Inc., 267 F.3d 400, 408 (5th Cir. 2001); Bryant v. Avado Brands, Inc., 187 F.3d 1271, 1282 (11 th Cir. 1999).

${ }^{41}$ See, e.g., Howard v. SEC, 376 F.3d 1136, 1143 (D.C. Cir. 2004).

42 See, e.g., In re Comshare, Inc. Sec. Litig., 183 F.3d 542, 550 (6th Cir. 1999).

${ }^{43}$ Ann Morales Olazábal, Defining Recklessness: A Doctrinal Approach to Deterrence of Secondary Market Securities Fraud, 2010 WIS. L. REV. 1415, 1424-25 [hereinafter Morales Olazábal, Defining Recklessness]; Ann Morales Olazábal, The Search for "Middle Ground": Towards a Harmonized Interpretation of the Private Securities Litigation Reform Act's New Pleading Standard, 6 STAN. J.L. BuS. \& FIN. 153, 162-64 (2001).

${ }^{44}$ Sundstrand Corp. v. Sun Chem. Corp., 553 F.2d 1033, 1045-47 (7th Cir. 1977).

${ }^{45}$ See, e.g., In re Level 3 Commc'ns, Inc. Sec. Litig., 667 F.3d 1331, 1343 n.12 (10th Cir. 2012); Findwhat Investors Grp. v. Findwhat.com, 658 F.3d 1282, 1300 (11 th Cir. 2011); Amacker v. Renaissance Asset Mgmt. LLC, 657 F.3d 252, 257-58 (5th Cir. 2011) (defining recklessness in the context of aiding and abetting violations); Miss. Pub. Emps. Ret. Sys. v. Bos. Scientific Corp., 649 F.3d 5, 20 (1st Cir. 2011); Dronsejko v. Thornton, 632 F.3d 658, 665 (10th Cir. 2011); Siracusano v. Matrixx Initiatives, Inc., 585 F.3d 1167, 1180 (9th Cir. 2009), aff'd, 131 S. Ct. 1309 (2011); Horizon Asset Mgmt. Inc. v. H \& R Block, Inc., 580 F.3d 755, 766 (8th Cir. 2009).

46 3B Kevin F. O'Malley et al., Federal Jury Practice \& Instructions: Civil $\S \S 162.232, .284$ (5th ed. 2012); see also PATTERN CIVIL JURY INSTRUCTIONS FOR THE 5TH CIRCUIT $\S 7.1$ (2009); MANUAL OF MODEL CIVIL JURY INSTRUCTIONS FOR THE DisTRICT COURT OF THE NINTH CIRCUIT: CIVIL $\$ 18.3(2007)$.

This is not to suggest that defendants cannot try to convince a jury that, despite the objective obviousness of the facts that they misrepresented, they nonetheless harbored a pure heart. See Allan Horwich, An Inquiry into the Perception of Materiality as an Element of Scienter Under SEC Rule 10b-5, 67 BUS. LAW. 1 (2011). The point is that a reasonable jury is permitted to infer an intent to deceive or recklessness from mere objective evidence of the materiality of the facts misrepresented.

${ }^{47}$ See, e.g., Matrixx Initiatives, Inc. v. Siracusano, 131 S. Ct. 1309, 1323-24 (2011); Merck \& Co. v. Reynolds, 130 S. Ct. 1784, 1796 (2010); Tellabs, Inc. v. Makor Issues \& 
impose liability for fraud is likewise consistent with the English common law and the majority of American common law on fraud. ${ }^{48}$ In sum, what scienter boils down to is that the plaintiff must allege and prove, at a minimum, that the defendant knowingly made a misleading statement or was reckless in disregarding a substantial risk that a statement was misleading. ${ }^{49}$

\section{THE CORE OPERATIONS INFERENCE OF SCIENTER: PLEADING RECKLESSNESS THROUGH MATERIALITY}

Defining a culpable state of mind is one thing, but pleading and proving it is another matter entirely. ${ }^{50}$ Conclusory allegations that the defendant acted with the requisite mental state will not suffice. ${ }^{51}$ And direct evidence of a person's state of mind is rare because this evidence is usually limited to an actual admission by the defendant under oath or the testimony of a witness based upon personal knowledge, both of which are unlikely to be available without discovery, ${ }^{52}$ which is stayed in securities litigation pending any motion to dismiss. $^{53}$ Thus, plaintiffs are often forced to rely on mental markers (circumstantial evidence) to allege a defendant's state of mind. ${ }^{54}$

Rights, Ltd., 551 U.S. 308, 319 n.3 (2007);.Ernst \& Ernst v. Hochfelder, 425 U.S. 185, 194 n.12 (1976).

${ }^{48}$ See Kevin R. Johnson, Liability for Reckless Misrepresentations and Omissions Under Section 10(b) of the Securities Exchange Act of 1934, 59 U. CIN. L. REV. 667, 696706 (1991); William H. Kuehnle, On Scienter, Knowledge, and Recklessness Under the Federal Securities Laws, 34 Hous. L. REV. 121, 166-71 (1997).

${ }^{49}$ See, e.g., Makor Issues' \& Rights, Ltd. v. Tellabs Inc. (Tellabs II), 513 F.3d 702, 704 (7th Cir. 2008); Higginbotham v. Baxter Int'l Inc., 495 F.3d 753, 756 (7th Cir. 2007).

50 ."What passes in the mind of man is not scrutable by any human tribunal; it is only to be collected from his acts." R v. Shipley, (1784) 99 Eng. Rep. 774, 828 (K.B.).

51 Ashcroft v. Iqbal, 129 S. Ct. 1937, 1949 (2009); Bell Atl. Corp. v. Twombly, 550 U.S. 544, 555 (2007).

524 Clifford S. Fishman, Jones ON Evidence: Civil AND Criminal $\$ 29: 1$ (7th ed. 2011). The Second Circuit has recognized the difficulty for plaintiffs in pleading scienter without "specifically greedy comments from ... authorized corporate individual[s]." Press v. Chem. Inv. Servs. Corp., 166 F.3d 529, 538 (2d Cir. 1999).

5315 U.S.C. $\& 78 \mathrm{u}-4(\mathrm{~b})(3)(2006)$.

${ }^{54}$ Herman \& MacLean v. Huddleston, 459 U.S. 375, 390 n.30 (1983). One set of allegations that may circumstantially suggest scienter in the Second Circuit, for example, is that the defendants had both a motive and an opportunity to commit fraud. See, e.g., ECA \& Local 134 IBEW Joint Pension Trust of Chi. v. JP Morgan Chase Co., 553 F.3d 187, 198-99 (2d Cir. 2009); Teamsters Local 445 Freight Div. Pension Fund v. Dynex Capital Inc., 531 F.3d 190, 195 (2d Cir. 2008).

For securities fraud claims, an added difficulty is locating where corporate scienter resides. The "meaning of scienter in the corporate environment" is "one of the great unexplored issues under Rule 10b-5." Donald C. Langevoort, The Epistemology of Corporate-Securities Lawyering: Beliefs, Biases, and Organizational Behavior, 63 BROOK. L. REV. 629, $660 \mathrm{n} .91$ (1997). Generally, plaintiffs plead the scienter of a corporation by alleging that the person responsible for the misstatement or omission possessed the requisite state of mind. See Bruce D. Angiolillo, Establishing Scienter in Securities Fraud Actions 
One of the mental markers plaintiffs often rely upon is the core operations inference. Under the core operations inference, plaintiffs allege that the subject of the fraud concerned a "core operation" of the company and thus the company's senior management, by virtue of their positions, either knew what they were saying was misleading or acted recklessly in not knowing what they were saying was misleading and speaking about it anyway. In other words, senior management is charged with knowledge about facts that are so material to the company and its investors, and when management speaks about these matters, they should ensure that they do so truthfully. This Part examines what constitutes a "core operation" and who is charged with knowledge of these core operations. This Part explains that the core operations inference recognizes a strong likelihood of scienter when misstatements concern matters material to the company, and it is senior management-who should be familiar with these matters-making these misleading statements.

\section{A. What Is a "Core Operation"?}

A "core operation" is a fact that is material to the company's operations and its bottom line, and as such it is something that is material to investors as well. ${ }^{55}$ Under the securities laws, a fact is material if "there is a substantial likelihood that a reasonable shareholder would consider it important" in making the investment decision. ${ }^{56}$ Generally, a core operation is thought of as the firm's primary product or service; as Judge Richard Posner put it, a core operation is like what "Windows XP and Vista are to Microsoft."57 Yet core operations encompass much more than just the company's core products or services. Courts have recognized that the core operations inference extends to any matter of importance that might affect the company in a significant way, including, as

Through Imputation of Knowledge, in 42ND ANNUAL INSTITUTE ON SECURITIES REGULATION 325, 344 (PLI Corp. Law \& Practice, Course Handbook Ser. No. B-1850, 2010). Plaintiffs may invoke the collective scienter theory, which allows plaintiffs to attribute scienter to the corporation without identifying a single actor who intentionally misspoke. In others words, the theory permits the aggregation in a single pleading of one person's misstatement with the intent of another person in order to attribute an allegation of scienter to the corporation. See generally Patricia S. Abril \& Ann Morales Olazábal, The Locus of Corporate Scienter, 2006 COLUM. BUS. L. REV. 81, 86.

${ }^{55}$ See, e.g., Freudenberg v. E*Trade Fin. Corp., 712 F. Supp. 2 d 171, 181 (S.D.N.Y. 2010) ("[M] aterial misrepresentations include those "concern[ing] a segment or other portion of the registrant's business that has been identified as playing a significant role in the registrant's operations or profitability." (emphasis omitted) (quoting SEC Staff Accounting Bulletin No. 99, 64 Fed. Reg. 45,150, 45,152 (Aug. 19, 1999))).

56 Basic Inc. v. Levinson, 485 U.S. 224, 231-32 (1988); TSC Indus., Inc. v. Northway, Inc., 426 U.S. 438, 449 (1976).

${ }^{57}$ Makor Issues \& Rights, Ltd. v. Tellabs Inc. (Tellabs II), 513 F.3d 702, 709 (7th Cir. 2008). 
just one example, important transactions. ${ }^{58}$ Viewing core operations as anything material to investors explains why the doctrine is invoked (though unsuccessfully at times) in cases involving accounting irregularities, which may not be the core products of the company, but nevertheless are so critical to the company's daily operations that one can expect management to be aware of them. ${ }^{59}$ Thus, at the most general level, the core operations inference recognizes that senior management is aware of facts that are material to the company, or at least considers these officers reckless if they ignorantly speak about these material facts.

If the core operations inference is understood as a common sense notion that senior management is or should be aware of facts material to the company and investors, then the inference is really nothing extraordinary. The federal courts have long recognized scienter's relationship to materiality. ${ }^{60}$ Two cases help illustrate this point. First, consider Cosmas v. Hassett ${ }^{61}{ }^{6}$ which predates both Tellabs and the PSLRA. In that case, the plaintiffs alleged the company's chief executive officer touted the company's sales to the People's Republic of China as an important new source of revenue and predicted increasing sales and per share earnings for the coming year. ${ }^{62}$ Before these announcements, however, the People's Republic of China imposed import restrictions that made

${ }^{58}$ See, e.g., Jones v. Corus Bankshares, Inc., 701 F. Supp. 2d 1014, 1028 (N.D. Ill. 2010 ) (stating that the core operations inference extends to important transactions that would affect the company's performance); In re Huffy Corp. Sec. Litig., 577 F. Supp. 2d 968, 1000 (S.D. Ohio 2008) (same); In re Sears, Roebuck \& Co. Sec. Litig., 291 F. Supp. 2d 722, 727 (N.D. Ill. 2003) (same).

${ }^{59}$ See Schultz v. Applica Inc., 488 F. Supp. 2d 1219, 1226 n.3 (S.D. Fla. 2007) (collecting cases). But see Ley v. Visteon Corp., 543 F.3d 801, 812 (6th Cir. 2008) (stating that knowledge of "obvious" accounting irregularities would not be imputed to executives because change in revenue caused by irregularities was too low); Ind. Elec. Workers' Pension Trust Fund IBEW v. Shaw Grp., Inc., 537 F.3d 527, 835-36, 839-40 (5th Cir. 2008) (refusing to infer "hands on" management knew of accounting irregularities with a value of "hundreds of millions of dollars").

${ }^{60}$ See, e.g., City of Dearborn Heights Act 345 Police \& Fire Ret. Sys. v. Waters Corp., 632 F.3d 751, 757 (1st Cir. 2011) ("If it is questionable whether a fact is material or its materiality is marginal, that tends to undercut the argument that defendants acted with the [scienter]." (citations omitted) (internal quotation marks omitted)); City of Phila. v. Fleming Co., 264 F.3d 1245, 1265 (10th Cir. 2001) ("[W]hether Defendants recklessly failed to disclose [a fact] is . . . intimately bound up with whether Defendants either actually knew or recklessly ignored that the [fact] was material and nevertheless failed to disclose it."); Transcript of Oral Argument at 43, Matrixx Initiatives, Inc. v. Siracusano, $131 \mathrm{~S}$. Ct. 1309 (2011) (No. 09-1156) (Scalia, J.) (stating that there really is no difference between scienter and materiality); see also Michael J. Kaufman, Living in a Material World: Strict Liability Under Rule 10b-5, 19 CAP. U. L. REV. 1, 3 (1990) (arguing scienter is actually bound up with materiality); Michael J. Kaufman, The Uniform Rule of Liability Under the Federal Securities Laws: The Judicial Creation of a Comprehensive Scheme of Investor Insurance, 63 TEMP. L. REV. 61, 62 (1990) (same).

61886 F.2d 8 (2d Cir. 1989).

62 Id. at 10. 
these predicted sales improbable. ${ }^{63}$ The Second Circuit held that the plaintiffs adequately alleged a strong inference of scienter because the allegations concerned a "significant source of income for the company." 64 The misleading statements from the company's CEO about facts so material to the company were enough for the court to infer scienter ${ }^{65}$

Second, consider Nathenson $v$. Zonagen Inc. ${ }^{66}$ a case that predates Tellabs but comes after the PSLRA. In Nathenson, the plaintiffs alleged that the president (who was also CEO and a director) of a biopharmaceutical company falsely represented that the company received patent approval for Vasomax, the company's potential drug. ${ }^{67}$ The company claimed in press releases that it received approval for a "method of use" patent that "broadly covered" items dissolved in the mouth; but in fact, Vasomax was to be dissolved in the stomach, and thus the patent did not cover it. ${ }^{68}$ The Fifth Circuit said these allegations were sufficient to generate a strong inference that the officer acted with scienter based on his positions (he was president, $\mathrm{CEO}$, and a director) ${ }^{69} \mathrm{It}$ would have been absurd to suggest the defendant was unaware of the lack of patent approval for Vasomax because the company "was essentially a one product company, and that product was Vasomax"; that "substantially all of the Company's efforts and expenditures over the next few years [were] devoted to Vasomax"; and that the president acknowledged that the approval of the patent was a "crucial event" for the company. ${ }^{70}$

\section{B. Who Should Have Knowledge of Core Operations?}

The inference recognizes that senior management (including officers and directors) likely have knowledge of the company's core operations. Presuming senior management's knowledge of core operations-or facts that are material to the company-is consistent with common sense, the common law, and the securities laws.

First, as a matter of common sense, we would expect senior management to be familiar with the company he or she is charged with running. The Sixth

\section{${ }^{63} I d$.}

${ }^{64}$ Id. at 13; see also In re Atlas Worldwide Holdings, Inc. Sec. Litig., 324 F. Supp. 2d 474, 491 (S.D.N.Y. 2004).

${ }^{65}$ Cosmas, 886 F.2d at 10-13; see also Shields v. Citytrust Bancorp, Inc., 25 F.3d 1124, 1130-31 (2d Cir. 1994) (interpreting Cosmas).

${ }^{66} 267$ F.3d 400 (5th Cir. 2001).

${ }^{67} \mathrm{Id}$. at $405-06$.

${ }^{68} \mathrm{Id}$. at 423,425 .

${ }^{69} \mathrm{Id}$. at $424-25$.

${ }^{70}$ Id. In In re Ancor Communications, Inc., Securities Litigation, 22 F. Supp. 2d 999 (D. Minn. 1998), also a pre-Tellabs case, the court inferred that key officers of the company must have known the company's product would be incompatible with the product of another company with whom the defendant had entered into a supply contract because the supply contract "was undeniably the most significant contract in [the defendant's] history." Id. at 1005 . 
Circuit made this point in Frank v. Dana Corp., where the plaintiffs alleged that two top executives of an automobile parts manufacturer misled the public about the company's ability to prosper at a time when (1) the entire auto industry was spiraling toward bankruptcy; (2) one of the company's "key product lines" was operating at $50 \%$ of earnings; (3) multiple factories failed to meet their budgets; and (4) the price of steel rose $75 \% .{ }^{71}$ The Sixth Circuit recognized that "[i]t is difficult to grasp the thought that [the two executives] really had no idea that [the company] was on the road to bankruptcy."72

One would expect senior management to be familiar with the company's core operations. Otherwise, the market would discredit their public statements. As Professor Geoffrey P. Miller illustrates when explaining why allegations of materiality further increase the probability that a defendant acted with scienter:

[S]ophisticated businesspeople understand that when information is materialwhen it is important to market actors in deciding whether to buy, sell, or hold the company's shares--they need to be especially careful to verify the truth of what they are saying, both for legal reasons (materiality being a predicate for liability under Rule 10b-5) and also for business purposes (the market will lose faith in the company if its officers make false statements about important facts)..$^{73}$

Apart from common sense, the law provides a basis for the inference as well. At common law, officers and directors owe fiduciary duties to the corporations they serve. ${ }^{74}$ These parties cannot carry out their owed duties of loyalty, good faith, and honesty without being cognizant of the company's core operations. ${ }^{75}$ Thus, directors and officers, though not required to know every

${ }^{71} 646$ F.3d 954, 961-62 (6th Cir. 2011).

72 Id. at 962.

${ }^{73}$ Miller, supra note 24, at 517.

${ }^{74}$ See, e.g., SEC v. Chenery Corp., 318 U.S. 80, 85 (1943) (explicitly rejecting a "lax view of fiduciary obligations" that officers owe to a holding company in the process of reorganization); see also 18B AM. JUR. 2D Corporations $\S 1460$ (2011) (collecting cases).

We clarify that by emphasizing duty's relationship to scienter, we do not suggest that securities fraud liability would be limited to only those who owe fiduciary duties to investors. We only suggest that an inference of scienter is more likely when those with a duty to know about the company's workings make misleading statements concerning those operations.

${ }^{75}$ See, e.g., In re Cumberland Farms, Inc., 284 F.3d 216, 231 (1st Cir. 2002) (recognizing that under Massachusetts law directors have a duty of reasonable supervision). A claim brought under In re Caremark International Inc. Derivative Litigation, 698 A.2d 959 (Del. Ch. 1996), permits officers and directors to be held liable for their inaction or ignorance of liability-creating activities within the corporation. "Caremark duties are breached when fiduciaries either fail to implement any reporting or information system or controls or, having implemented [these] controls, consciously fail to oversee their operation, thus disabling themselves from being informed of risks or problems requiring their attention." In re Brocade Commc'ns Sys., Inc. Derivative Litig., 615 F. Supp. 2d 1018, 1048 (N.D. Cal. 2009). 
nook and cranny of corporate doings, have a duty to familiarize themselves with at least the company's core operations. ${ }^{76}$

Additionally, under the securities laws both the fraud-on-the-market theory and the Sarbanes-Oxley Act of 2002 (SOX) support inferring that senior management has or should have knowledge about the company's core operations. 77 To begin, as Professor Morales Olazábal recognizes, "[W]hen top corporate officers misspeak to the marketplace about material matters, harm to investors is not only possible, but likely."78 Public misstatements about material facts made on an efficient market are presumed to have an effect on the stock price; this is the essence of the fraud-on-the-market theory and the underlying efficient market hypothesis, which the Supreme Court has endorsed most recently in Erica P. John Fund, Inc. v. Halliburton Co. ${ }^{79}$

In addition, SOX's requirements that executives certify financial reports support the idea that senior management should be held accountable to investors for misleading statements concerning core operations. ${ }^{80}$ SOX requires the principal executive officer and principal financial officer to certify that they have reviewed the quarterly Form $10-\mathrm{Q}$ and annual Form $10-\mathrm{K}$ reports and that these reports do not contain any untrue statement or material omission. ${ }^{81}$ This provision is not unreasonable- "Would anybody buy a company's stock if they

${ }^{76}$ See Stratte-McClure v. Stanley, 784 F. Supp. 2d 373, 389 (S.D.N.Y. 2011).

${ }^{77}$ Robert B. Thompson and Professor Hillary A. Sale persuasively show that the "federal securities law and enforcement via securities fraud class actions today have become the most visible means of regulating corporate governance." Robert B. Thompson \& Hillary A. Sale, Securities Fraud as Corporate Governance: Reflections upon Federalism, 56 VAND. L. REV. 859, 860 (2003).

As additional evidence that senior management is presumed to have knowledge of core operations under the securities laws, consider Section 16(b). Section 16(b) of the 1934 Act requires statutory insiders-officers, directors, and shareholders with more than a $10 \%$ interest in the issuing company-to disgorge profits from short-swing trading. 15 U.S.C. $\S 78 \mathrm{p}(\mathrm{b})(2006)$. This disgorgement rule is premised on the idea that these statutory insiders are "presumed to have access to inside information." Foremost-McKesson, Inc. v. Provident Sec. Co., 423 U.S. 232, 243 (1976) (emphasis added).

78 Morales Olazábal, Defining Recklessness, supra note 43, at 1428. Professor Hillary A. Sale argues even further that the new "publicness" of companies means that executives and officers must address expectations not only of its shareholders, but also of "Main Street" in general about what a company can and will do. See generally Hillary A. Sale, The New "Public" Corporation, 74 LAW \& CONTEMP. PROBS. 137 (2011).

79131 S. Ct. 2179, 2184-85 (2011); see also Basic Inc. v. Levinson, 485 U.S. 224, 246-47 (1988).

${ }^{80}$ S. REP. No. 107-205, at 23 (2002) ("[SOX] requires CEOs and CFOs to certify their companies' financial reports, outlaws fraud and deception by managers in the auditing process, prevents CEOs and CFOs from benefitting from profits they receive as a result of misstatements of their company's financials, and facilitates the imposition of judicial bars against officers and directors who have violated the securities laws."); see also Morales Olazábal, Defining Recklessness, supra note 43, at 1447-48.

81 15 U.S.C. § 7241; 17 C.F.R. § 240.13a-1 (2011). 
knew its officers could not make such a statement?"82 Indeed, as the Ninth Circuit observed, an officer's signature is "rendered meaningless unless the officer believes that the statements in the document are true." 83

${ }^{82}$ Charles W. Murdock, Why Not Tell the Truth?: Deceptive Practices and the Economic Meltdown, 41 LOY. U. CHI. L.J. 801, 836 (2010). Professor Murdock makes a compelling case for the reasonableness of the SOX's certification requirement:

[T] assess how reasonable or unreasonable the provisions of Section 302 are, it might be helpful to look at the regulations promulgated pursuant to Section 302, which set forth the certification that the officers are required to give. But rather than look at the certification itself, let's look at its negative. In other words, what would the antithesis of the required certification look like? I suggest it might look something like this:

I, [identify the certifying individual], certify that:

1. I have [not] reviewed this [specify report] of [identify registrant];

2. Based on my knowledge, this report [may] does not contain any untrue statement of a material fact or omit to state a material fact necessary to make the statements made, in light of the circumstances under which such statements were made, not misleading with respect to the period covered by this report;

3. Based on my knowledge, the financial statements, and other financial information included in this report, [may or may not; I really don't know] fairly present in all material respects the financial condition, results of operations and cash flows of the registrant as of, and for, the periods presented in this report;

4. The registrant's other certifying officer(s) and I are [not] responsible for establishing and maintaining disclosure controls and procedures (as defined in Exchange Act Rules 13a-15(e) and 15d-15(e)) and internal control over financial reporting (as defined in Exchange Act Rules 13a-15(f) and 15d-15(f)) for the registrant and have:

a. [Not] Designed such disclosure controls and procedures, or caused such disclosure controls and procedures to be designed under our supervision, to ensure that material information relating to the registrant, including its consolidated subsidiaries, is made known to us by others within those entities, particularly during the period in which this report is being prepared;

b. [Not] Designed such internal control over financial reporting, or caused such internal control over financial reporting to be designed under our supervision, to provide reasonable assurance regarding the reliability of financial reporting and the preparation of financial statements for external purposes in accordance with generally accepted accounting principles;

c. [Not] Evaluated the effectiveness of the registrant's disclosure controls and procedures and [we have no] presented in this-repurt conclusions about the effectiveness of the disclosure controls and procedures, as of the end of the period covered by this report based on such evaluation; and

d. [Not] Disclosed in this report any change in the registrant's internal control over financial reporting that occurred during the registrant's most recent fiscal quarter (the registrant's fourth fiscal quarter in the case of an annual report) that has materially affected, or is reasonably likely to materially affect, the registrant's internal control over financial reporting; and

5. The registrant's other certifying officer(s) and I have disclosed, based on our most recent evaluation of internal control over financial reporting, to the registrant's auditors and the audit committee of the registrant's board of directors (or persons performing the equivalent functions): 
SOX also imposes duties on certifying officers to: (1) establish and maintain internal controls that are designed to ensure that material information is made known to officers; and (2) disclose to the audit committee any deficiencies in the internal-control design and any fraud involving an officer or employee who has a significant role related to the company's internal controls. ${ }^{84}$ Any executive who willfully certifies a periodic financial statement knowing that the report contains misleading statements is subject to twenty years imprisonment and a fine of up to $\$ 5$ million. ${ }^{85}$ Although most federal courts state that false SOX certifications alone do not create a strong inference of scienter, ${ }^{86}$ courts nevertheless use SOX certification as justification to require management to familiarize themselves with the facts relevant to the company's financial statement before signing documents filed with the SEC. 87

The defendant's role is necessary to assess whether the defendant should have known or inquired about certain facts. Indeed, before the Supreme Court announced in Ernst \& Ernst $v$. Hochfelder that negligence was not sufficient to impose liability under Rule 10b-5, some federal courts adopted a "flexible duty" standard to determine whether and to what extent scienter was required. ${ }^{88}$ Even after Hochfelder, the flexible-duty approach reappears in the guise of

a. [We have no idea whether there are] All significant deficiencies and material weaknesses in the design or operation of internal control over financial reporting which are reasonably likely to adversely affect the registrant's ability to record, process, summarize and report financial information; and

b. [We have no idea whether there has been] Any fraud, whether or not material, that involves management or other employees who have a significant role in the registrant's internal control over financial reporting.

If management of a company filed the foregoing certification, would anyone buy stock in such a company? Why then cannot corporate management assert the positive, since the negative is unacceptable?

Charles W. Murdock, Sarbanes-Oxley Five Years Later: Hero or Villain, 39 LOY. U. CHI. L.J. 525, 540-42 (2008) (alterations in original) (emphases omitted).

83 Howard v. Everex Sys., Inc., 228 F.3d 1057, 1061 (9th Cir. 2000).

84 15 U.S.C. $\$ 7241$ (a)(4)-(5).

8518 U.S.C. $\$ 1350(c)(1)-(2)$.

${ }^{86}$ See, e.g., Zucco Partners, LLC v. Digimarc Corp., 552 F.3d 981, 1103-04 (9th Cir. 2009); In re Ceridian Corp. Sec. Litig., 542 F.3d 240, 248 (8th Cir. 2008); Ind. Elec. Workers' Pension Trust Fund IBEW v. Shaw Grp., Inc., 537 F.3d 527, 545 (5th Cir. 2008); Garfield v. NDC Health Corp., 466 F.3d 1255, 1266 (11 th Cir. 2006).

${ }^{87}$ See, e.g., In re Alstom SA Sec. Litig., 406 F. Supp. 2d 433, 473 (S.D.N.Y: 2005); In re Atlas Air Worldwide Holdings, Inc. Sec. Litig., 324 F. Supp. 2d 474, 491 (S.D.N.Y. 2004).

Although SOX explicitly does not provide for any private right of action, under tort law, a statute may yet impose an affirmative duty. See generally RESTATEMENT (THIRD) OF TORTS: Physical \& EMOTIONAL HARM $§ 38$ (2005); RESTATEMENT (SECOND) OF TORTS $\S 286(1965)$.

${ }^{88}$ See generally White v. Abrams, 495 F.2d 724 (9th Cir. 1974), overruled by Hollinger v. Titan Capital Corp., 914 F.2d 1564, 1570 (9th Cir. 1990) (en banc). 
determining whether one's conduct was reckless. ${ }^{89}$ The core operations inference recognizes that senior management stand as both fiduciaries and as officers of publicly held companies, and thus they appreciate the economic harm that would flow from public misstatements about material facts.

Focusing on the defendant's role does not reintroduce liability under Rule $10 \mathrm{~b}-5$ for breach of fiduciary duty or mere negligence, which the Supreme Court has rejected in Santa Fe Industries, Inc. v. Green ${ }^{90}$ and Ernst \& Ernst v. Hochfelder, ${ }^{91}$ respectively. Scienter premised on the core operations inference is predicated on facts that are so material that to suggest that the company's management was unaware of them or to excuse management from knowing about them would be absurd.

Persons responsible for staying abreast of these kinds of facts (the company's core operations) likely include persons other than just the company's principal officers. The company's directors should also have knowledge of core operations. In a case decided by the Ninth Circuit after the PSLRA, No. 84 Employer-Teamster Joint Council Pension Trust Fund v. America West Holding Corp., the plaintiffs alleged no particular facts to show that the company's outside directors knew about maintenance problems at the company or about the government's investigation of those problems..$^{92}$ In place of particularized allegations, the plaintiffs relied on an inference based on the directors' positions on the company's board: The plaintiffs argued - and the Ninth Circuit agreed - that the company's maintenance problems and the government's investigation into them were so important to the company that it was "absurd to suggest that the Board of Directors would not discuss" them. ${ }^{93}$

In sum, by assuming senior management, by virtue of their positions, were or should have been aware of facts so material to the company's core operations, the core operations inference enables plaintiffs to plead recklessness without particularized allegations of their mental state. The core operations inference represents the quotidian notion that it is likely that senior management charged with knowing facts material to the company's core operations do in fact know these facts, and that they would not make misleading statements about them if cognizant that doing so would cause investors harm. The inference thus premises scienter on two concepts: materiality and duty.

${ }^{89} 3$ B Harold S. BloOmenthal \& SAMUEl WolfF, Securities and Federal CORPORATE LAW $\S 13: 22$ ( $2 \mathrm{~d}$ ed. 2011). The drafters of the American Law Institute's Federal Securities Code likewise recognized that the meaning of recklessness depends to some extent on the particular defendant's role or position. FED. SEC. CODE $\S 202(86) \mathrm{cmt}$. $8(d)(1980)$.

90430 U.S. $462,474-75$ (1977).

91425 U.S. $185,193(1976)$.

92320 F.3d 920, 942-43 (9th Cir. 2003).

${ }^{93}$ Id. at 943 n.21; see also Cosmas v. Hassett, 886 F.2d 8, 13 (2d Cir. 1989) (imputing knowledge to entire board of directors under the core operations inference). But see In re Forest Labs., Inc. Derivative Litig., 450 F. Supp. 2d 379, 391 (S.D.N.Y. 2006) (holding that "there [was] no authority to support the attribution of knowledge to Outside Directors who [were] not alleged to be directly involved in the day-to-day operations of the company"). 


\section{A Note About the Core Operations Inference, Summary Judgment, and Trial}

At this point, we specifically address the viability of the core operations inference at summary judgment and trial, and we suggest that the inference is a viable method for overcoming summary judgment motions and meeting the plaintiff's burden at trial because the inference is just that - an inference drawn from circumstantial evidence. Thus, so long as the plaintiff offers evidence from which a reasonable trier of fact could find the facts supporting the core operations inference, then the plaintiff has offered sufficient circumstantial evidence from which a reasonable trier of fact could find scienter.

We have been unable to locate any reported decisions that directly address the scope or viability of the core operations inference on summary judgment or trial. On the one hand, the higher standard at summary judgment and trial suggests that the core operations inference may be insufficient. Tellabs stated that the burden at the motion-to-dismiss stage is less than the burden plaintiffs are faced with at trial:

A plaintiff alleging fraud in a $\S 10(\mathrm{~b})$ action ... must plead facts rendering an inference of scienter at least as likely as any plausible opposing inference. At trial, she must then prove her case by a "preponderance of the evidence." Stated otherwise, she must demonstrate that it is more likely than not that the defendant acted with scienter. ${ }^{94}$

One might conclude that to the extent the core operations inference suggests that it is only at least as likely that the defendant acted with scienter, then the inference alone may not be sufficient at summary judgment or trial.

But should the plaintiff prove at trial or offer evidence from which a reasonable trier of fact could find the facts underlying the inference - that senior management made misleading statements about facts pertaining to the company's core operations - this would provide circumstantial evidence of scienter that is sufficient to overcome summary judgment and to satisfy the burden at trial. The Supreme Court has recognized that circumstantial evidence alone is "more than sufficient" to prove scienter. 95

Consider In re NeoPharm, Inc. Securities Litigation, where the court held that a reasonable jury could find scienter from the plaintiff's evidence that the defendant, a pharmaceutical company, and its senior management, made false and misleading statements about development delays for its "lead product in development" that was "a potentially revolutionary method of administering

94 Tellabs, Inc. v. Makor Issues \& Rights, Ltd., 551 U.S. 308, 328-29 (2007) (emphases omitted); cf. Howard v. Everex Sys., Inc., 228 F.3d 1057, 1064 (9th Cir. 2000) ("Because the PSLRA did not alter the substantive requirements for scienter under $\S 10(\mathrm{~b})$, however, the standard on summary judgment . . remains unaltered . ...").

${ }^{95}$ Herman \& MacLean v. Huddleston, 459 U.S. 375, 390-91 n.30 (1983). 
[an] anti-cancer drug."96 The court did not mention the core operations inference, but still, this was the only evidence of scienter that the court discussed, implicitly supporting the notion that the core operations inference is sufficient at summary judgment and trial.

\section{THE CURRENT SLIDING-SCALE APPROACH TO THE CORE OPERATIONS INFERENCE}

We now turn to the federal courts' sliding scale for the core operations inference. The sliding-scale approach is best understood as the federal courts' attempt to cope with the tension between the inference and the PSLRA's particularity requirement.

Tellabs demands that district courts assess scienter holistically. ${ }^{97}$ In light of Tellabs, several federal courts have held that whether the fraud concerns a company's core operations is just one factor considered in the holistic scienter analysis. ${ }^{98}$ The Third Circuit in Institutional Investors Group v. Avaya, Inc. implicitly recognized the core operations inference as a factor in that gestalt analysis. There, the plaintiffs did not provide particularized allegations to show that the defendant's CEO and CFO knew about substantial price-discounting practices, but the court still held that the complaint alleged a strong inference of scienter because price discounting threatened to destabilize the company's ability to increase sales without cutting prices, which was viewed as key to the

96705 F. Supp. 2d 946, 949, 968-69 (N.D. Ill. 2010). The district court in Feinberg $v$. Benton, No. 05-4847, 2007 WL 4355408 (E.D. Pa. Dec. 13, 2007), also implicitly recognized that the core operations inference alone might be sufficient for a reasonable jury to find scienter where the subject of the fraud concerned the company's core business. Id. at *6.

${ }^{97}$ Tellabs, 551 U.S. at 323-24. The Ninth Circuit conducts a two-part inquiry:

[First, the court determines] whether any of the allegations, standing alone, are sufficient to create a strong inference of scienter; second, if no individual allegation is sufficient, [the court] conduct[s] a "holistic" review of the same allegations to determine whether the insufficient allegations combine to create a strong inference of intentional conduct or deliberate recklessness.

N.M. State Inv. Council v. Ernst \& Young LLP, 641 F.3d 1089, 1095 (9th Cir. 2011); see also Zucco Partners, LLC v. Digimarc Corp., 552 F.3d 981, 991-92 (9th Cir. 2009). The Ninth Circuit appears to be alone in this approach. See Frank v. Dana Corp., 646 F.3d 954, 961 (6th Cir. 2011); Slayton v. Am. Express Co., 604 F.3d 758, 775 (2d Cir. 2010).

98 See, e.g., Sharenow v. Impac Mortg. Holdings, Inc., 385 F. App'x 714, 717 (9th Cir. 2010) (nonprecedential disposition); Institutional Investors Grp. v. Avaya, Inc., 564 F.3d 242, 268-70 (3d Cir. 2009); S. Ferry LP, No. 2 v. Killinger, 542 F.3d 776, 784 (9th Cir. 2008); Warchol v. Green Mountain Coffee Roasters, Inc., No. 2:10-cv-227, 2012 WL 256099, at *11 (D. Vt. Jan. 27, 2012); In re Nvidia Corp. Sec. Litig., No. 08-CV-04260-RS, 2010 WL 4117561 , at *10 (N.D. Cal. Oct. 19, 2010); In re Taleo Corp. Sec. Litig., No. C 09-00151 JSW, 2010 WL 597987, at *9 (N.D. Cal. Feb. 17, 2010); Kelley v. Rambus, Inc., No. C 07-1238 JF (HRL), 2008 WL 5170598, at *6 (N.D. Cal. Dec. 9, 2008). 
company's success. ${ }^{99}$ The Ninth Circuit, in South Ferry LP, No. 2 v. Killinger, made explicit what was implicit in Avaya, and said that the core operations inference is one factor in a holistic analysis, but then continued to restrict the inference in a sliding-scale test in order to reconcile the inference with the particularity requirement. ${ }^{100}$ Under this sliding-scale approach, the more material the fact is to the company, the less the need for particularized allegations concerning senior-level management's actual knowledge, and vice versa. As these next parts show, several federal courts have employed this sliding scale, many without so stating.

\section{A. The More Significant the Fact Is to the Company, the More Indicative of Scienter and the Less the Need for Particularized Allegations}

The PSLRA's particularity requirement often stands in the way of the core operations inference. Several federal courts have cursorily stated that the fact that a misleading statement relates to the company's core operations standing alone is insufficient to support a strong inference of scienter because of the lack of particularized allegations. ${ }^{101}$ But this is not always true. In fact, several other cases have overlooked the lack of particularized allegations when misleading statements concerned core operations-facts of which senior management must or should have been aware. ${ }^{102}$

One of the better examples of softening the particularity requirement in the face of misstatements about facts so material to the company is Berson $v$. Applied Signal Technology, Inc. ${ }^{103}$ In that case, the plaintiffs sued Applied Signal Technology and two of its officers, claiming that the defendants misled investors into thinking that the company was likely to perform work when in reality it was not. ${ }^{104}$ The company's customers were almost all agencies of the federal government; two civilian agencies accounted for $80 \%$ of the company's revenue, and military agencies accounted for the rest. ${ }^{105}$ These government

${ }^{99}$ Institutional Investors Grp., 564 F.3d at 268-70.

100542 F.3d at 784; see also Sharenow, 385 F. App'x at 717.

101 See, e.g., Glaser v. The9, Ltd., 772 F. Supp. 2d 573, 595 (S.D.N.Y. 2011); Plumbers Union Local No. 12 Pension Fund v. Ambassador's Grp., 717 F. Supp. 2d 1170, 1179 (E.D. Wash. 2010).

102 See, e.g., Stratte-McClure v. Stanley, 784 F. Supp. 2d 373, 389-90 (S.D.N.Y. 2011); In re Reserve Fund Sec. \& Derivative Litig., 732 F. Supp. 2d 310, 322-24 (S.D.N.Y. 2010); Plumbers Union Local No. 12 Pension Fund, 717 F. Supp. 2d at 1179; Freudenberg v. E*Trade Fin. Corp., 712 F. Supp. 2d 171, 199-201 (S.D.N.Y. 2010); Jones v. Corus Bankshares, Inc., 701 F. Supp. 2d 1014, 1028-29 (N.D. Ill. 2010); Desai v. Gen. Growth Props., Inc., 654 F. Supp. 2d 836, 860 (N.D. Ill. 2009); Silverman v. Motorola, Inc., No. 07 C 4507, 2008 WL 4360648, at *14 (N.D. Ill. Sept. 23, 2008); In re LDK Solar Sec. Litig., 584 F. Supp. 2d 1230, 1249-50 (N.D. Cal. 2008); In re Sears, Roebuck \& Co. Sec. Litig., 291 F. Supp. 2d 722, 727 (N.D. 111. 2003).

103527 F.3d 982 (9th Cir. 2008).

104 Id. at 984 .

105 Id. 
customers could, at any time, order the company to stop working on existing contacts through a "stop-work order."106 If the government issued a stop-work order, then the company immediately ceased to earn money; the company only got paid for work it actually performed, and stopped work often was eventually cancelled altogether. The government issued four stop-work orders - which halted tens of millions of dollars of work that the company contracted to dobut the company continued to count the stopped work as part of its "backlog," a term the company defined as "the dollar value of the work it has contracted to do but hasn't yet performed."107

The plaintiffs alleged that the company's two officers must have been aware of the stop-work orders, yet counted the stopped work as part of its backlog anyway. The plaintiffs did not have any "particular facts indicating that [the executives] actually knew about the stop-work orders."108 Instead, the Ninth Circuit said, "[P]laintiffs infer that these high-level managers must have known about the orders because of their devastating effect on the corporation's revenue." 109 And the stop-work orders' effect was devastating: the first stopwork order halted between $\$ 10$ million and $\$ 15$ million of work; the second halted $\$ 8$ million of work, and the third caused the company to reassign fifty to seventy-five employees, with the result that one of the company's facilities became a "ghost town." 110 The Ninth Circuit held that the plaintiffs adequately alleged a strong inference of scienter because (1) the executives "were directly responsible for Applied Signal's day-to-day operations"; and (2) "it is hard to believe that they would not have known about stop-work orders that allegedly halted tens of millions of dollars of the company's work."111

It is important to note, though, that the Ninth Circuit had more to go on to find scienter than just the materiality of the facts to the company, but not much (as is often the case)..$^{112}$ In addition to the core operations inference, the court also relied on the fact that one of the misleading statements was close in time to the disclosure of the fraud and that a confidential witness claimed that management unsuccessfully tried to negotiate away some requirements of the work contracts to stave off their cancellation. ${ }^{113}$ These additional facts, though, would not have made the plaintiffs' case a slam dunk. While the temporal

106 Id.

107 Id.

108 Id. at 987.

109 Berson, 527 F.3d at 987 (emphasis omitted).

110 Id. at 988 n.5.

111 Id. at 988 .

112 For examples of cases in which the court infers scienter based primarily on the core operations inference but also other weaker circumstantial evidence, see Sgalambo $v$. McKenzie, 739 F. Supp. 2d 453, 481 (S.D.N.Y. 2010), In re RAIT Financial Trust Securities Litigation, No. 2:07-cv-03148-LDD, 2008 WL 5378164, at*12 (E.D. Pa. Dec. 22, 2008), In re Huffy Corp. Securities Litigation, 577 F. Supp. 2d 968, 999-1000 (S.D. Ohio 2008), and City of Sterling Heights Police \& Fire Retirement System v. Abbey National, PLC, 423 F. Supp. 2d 348, 361-62 (S.D.N.Y. 2006).

${ }^{113}$ Berson, 527 F.3d at 988. 
proximity of a misstatement to the revelation of the truth is no doubt suggestive of scienter, courts are reluctant to infer scienter on temporal proximity alone. ${ }^{114}$ And the Ninth Circuit has been most stringent when reviewing allegations from confidential witnesses. 115 Thus, the Ninth Circuit in Berson returned to the fact that the matter was "prominent enough that it would be 'absurd to suggest' that top management was unaware of [it]" as a basis for ultimately inferring scienter. ${ }^{116}$

Another leading example that illustrates the particularity requirement giving way to a strong inference of scienter is Makor Issues \& Rights, Ltd. v. Tellabs Inc. (Tellabs II). ${ }^{117}$ That case was one of "classic fraud," as the plaintiffs put it. ${ }^{118}$ In Tellabs $I I$, the company, a manufacturer of fiber optic cable networks, and its CEO announced that the replacement for the company's flagship product was "available now," and that a telephone company signed a $\$ 100$ million contract to buy this new product. 119 The company and its CEO also repeatedly touted the growth of the original as well as the replacement product. 120 Yet from the start, the company was flooding customers with tens of millions of dollars worth of the original product that customers did not order to create the illusion of demand ("channel stuffing"). The company even leased extra storage space to house the large number of returns. 121 Eventually, the company announced a major drop in revenue, and the company's largest customer cut its product order in half. During the class period, not a single unit of the replacement product was shipped. ${ }^{122}$

How likely was it that the allegedly false statements concerning the company's products were the result of careless mistakes rather than an intent to deceive or a reckless indifference to whether the statements were misleading? Even in the absence of particularized allegations of the CEO's actual

114 See, e.g., Elam v. Neidorff, 544 F.3d 921, 930 (8th Cir. 2008); Fidel v. Farley, 392 F.3d 220, 232 (6th Cir. 2004).

115 See, e.g., In re Silicon Graphics Inc. Sec. Litig., 183 F.3d 970, 985, 988 (9th Cir. 1999).

${ }^{116}$ Berson, 527 F.3d at 989 . The court's reliance on No. 84 Employer-Teamster Joint Council Pension Trust Fund v. America West Holding Corp., 320 F.3d 920 (9th Cir. 2003), bolsters this conclusion. In America West, the court inferred that outside directors must have been aware of the company's maintenance problems and a government investigation because it would have been absurd to suggest the board wasn't discussing these problems. There were no particularized allegations of knowledge in that case either. Id. at 942-43.

117513 F.3d 702 (7th Cir. 2008).

118 Reply Brief for Plaintiffs-Appellants at 1, Tellabs II, 513 F.3d 702 (No. 04-1687).

119 Tellabs II, 513 F.3d at 706.

120 Id.

${ }^{121}$ Id. This is generally known as "channel stuffing," a practice where a company ships more of one's product than one thinks a distributor can sell. Sometimes this is used to incite sales, but when it is used to book revenues on the basis of goods shipped but not really sold, then it becomes a form of fraud. Id. at 709 .

${ }^{122} \mathrm{Id}$. at 707. 
knowledge, according to the Seventh Circuit, it was "exceedingly unlikely."123 The court explained that the products were the company's "most important products"; it was as if "General Motors announced that it had sold one million SUVs in 2006, and the actual number was zero." 124 The plaintiffs did not offer particularized facts that the company's CEO knew about the declining demand, and yet the court held that the plaintiffs adequately alleged that the company's executives acted with scienter "since so dramatic an announcement would have been approved by corporate officials sufficiently knowledgeable about the company to know that the announcement was false."125

Similar to Berson, the Seventh Circuit in Tellabs $I I$ had more than just misleading statements from senior management about the company's core products to infer scienter, although also like Berson these additional allegations do not seem to represent the tipping point in inferring scienter. For example, the court relied upon the fact that the company paid $\$ 100,000$ to a consulting company to forecast demand for its products, which showed the market was evaporating, and that twenty-six confidential sources would confirm these allegations. ${ }^{126}$ But the Seventh Circuit in Higginbotham v. Baxter International, Inc., also said that "[o]ne upshot of the approach that Tellabs announced is that we must discount allegations that the complaint attributes to ... 'confidential witnesses" "and "[u]sually that discount will be steep."127

The court also relied on the facts that the defendants engaged in channel stuffing, that the company leased a warehouse to store the huge number of returns, and that the company's largest customer even called to complain about products shipped that were not ordered. ${ }^{128}$ But the court's analysis really just looped back to the core operations inference. Channel stuffing can be either legitimate (i.e., prodding distributors to move more product) or illegitimate (i.e., a way to hide dwindling demand for a product). ${ }^{129}$ The court thought that the channel stuffing in this case suggested scienter, however, for two reasons. First, channel stuffing was used to "book revenues on the basis of goods shipped but not really sold because the buyer can return them," making them "in effect sales on consignment, and such sales "cannot be booked as revenue." 130 Second, the

123 Id. at 709 .

${ }^{124} \mathrm{Id}$. at 709-10. Indeed, in the company's annual report, the CEO acknowledged that the company's "core business is built on" the products that were the subject of the fraud. Makor Issues \& Rights, Ltd. v. Tellabs Inc. (Tellabs I), 437 F.3d 588, 592 (7th Cir. 2006).

125 Tellabs II, 513 F.3d at 710.

${ }^{126}$ Id. at $709-12$.

127495 F.3d 753, 756-57 (7th Cir. 2007).

128 Tellabs II, 513 F.3d at 709-10.

${ }^{129}$ See, e.g., Tellabs, Inc. v. Makor Issues \& Rights, Ltd., 551 U.S. 308, 325 (2007); Tellabs II, 513 F.3d at 709 ("A certain amount of channel stuffing could be innocent and might not even mislead-a seller might have a realistic hope that stuffing the channel of distribution would incite his distributors to more vigorous efforts to sell the stuff lest it pile up in inventory."); Garfield v. NDC Health Corp., 466 F.3d 1255, $1261-62$ (11th Cir. 2006); Greebel v. FTP Software, Inc., 194 F.3d 185, 202-03 (1 st Cir. 1999).

${ }^{130}$ Tellabs II, 513 F.3d at 709. 
court reasoned that because the number of returns was so significant (i.e., material to the company), senior management must have been aware of it:

The huge number of returns of [the original product] is evidence that the purpose of the stuffing was to conceal the disappointing demand for the product rather than to prod distributors to work harder to attract new customers, and the purpose would have been formed or ratified at the highest level of management. ${ }^{131}$

More often, though, the core operations inference supplements already particularized allegations of the defendant's state of mind. ${ }^{132}$ In In re Countrywide Financial Corp. Securities Litigation, the court used the core operations inference to bolster a strong inference of scienter in fraud claims against a prominent real estate company, Countrywide. ${ }^{133}$ The plaintiffs alleged that the company relaxed its lending standards to approve more loans to highrisk borrowers while the company's "officers publicly denied that underwriting standards had deteriorated." 134 The court used the core operations inference to strongly infer that Countrywide's chief operating officer (COO), who publicly denied that the company lowered lending standards, acted with scienter. Additionally, the plaintiffs had particularized allegations that the $\mathrm{COO}$ sat in numerous review and strategy committee meetings relating to the company's

$131 \mathrm{Id}$. at 710.

132 See, e.g., New Orleans Emps. Ret. Sys. v. Celestica, Inc., No. 10-4702-cv, 2011 WL 6823204, at *2 n.3 (2d Cir. Dec. 29, 2011) (collecting cases and stating that "Both parties.... agree that allegations of a company's core operations... can provide supplemental support for allegations of scienter, even if they cannot establish scienter independently. That view finds support in decisions by this court and district courts within this circuit." (later citing cases)); In re Daou Sys., Inc., 411 F.3d 1006, 1022-23 (9th Cir. 2005); Nursing Home Pension Fund, Local 144 v. Oracle Corp., 380 F.3d 1226, 1231 (9th Cir. 2004); Centaur Classic Convertible Arbitrage Fund Ltd. v. Countrywide Fin. Corp., 793 F. Supp. 2d 1138, 1146 (C.D. Cal. 2011); S. Ferry LP, No. 2 v. Killinger, 687 F. Supp. 2d 1248, 1260-62 (W.D. Wash. 2009). A recent case illustrates how the core operations inference bolsters existing allegations quite well. In In re Toyota Motor Corp. Securities Litigation, No. CV10-922 DSF, 2011 WL 2675395 (C.D. Cal. July 7, 2011), the plaintiffs alleged that the company and its executives made misleading statements about unintended acceleration problems with the company's cars. Id. at *4. The plaintiffs offered an email from a vice president in which he admitted that the cars were having mechanical problems that resulted in unintended acceleration. $I d$. at *3. The district court concluded that the plaintiffs adequately alleged scienter because of this admission and also went on to conclude that the core operations inference would have established scienter. $I d$. at $* 3-4$. According to the court, the defects were "too significant for it to be plausible that top Toyota management was not aware of the possible ramifications of the problem," because " $[t]$ he magnitude of the problem was overwhelming, both in its potential catastrophic results and the number of vehicles involved," "[t] he likely cost was extraordinary; the resultant financial impact was admittedly significant; and the regulatory scrutiny was intense." Id. at *4.

133588 F. Supp. 2d 1132, 1194 (C.D. Cal. 2008).

134 Id. at 1146 . 
lending practices, and had access to numerous detailed reports. ${ }^{135}$ All this evidence, combined with his position as $\mathrm{COO}$, established a strong inference of scienter. ${ }^{136}$ The court said that the "alleged underwriting quality and credit risk management issues were so fundamental to Countrywide, and on such a broad scale, [it] should have been so apparent that it would be difficult to conclude that those Defendants at the top levels of Countrywide management did not know what was going on."'l37 Countrywide may not be a typical case; the court explained that Countrywide presented an "extraordinary case where a company's essential operations were so at odds with the company's public statements." 138 And the other courts to address $10 \mathrm{~b}-5$ suits in the context of the financial crisis and the subprime meltdown are generally reluctant to infer scienter. ${ }^{139}$

Nonetheless, these cases show that plaintiffs may establish a strong inference of scienter through the core operations inference alone or at least primarily without particularized allegations. This is no easy task; in just pleadings, plaintiffs must convince a court that the matter is so material that senior management must have been aware of it. Many federal district courts deal with the core operations inference simply by deeming the subject something that, although material, is not material enough such that senior management must have been aware of it. ${ }^{140}$ This pushes the case to the other end of the spectrum where the court deems the facts less significant and thus less indicative of scienter and, therefore, in need of particularized allegations.

${ }^{135} I d$. at 1194.

136 Id.

${ }^{137}$ Id. (emphasis added) (quoting In re Countrywide Fin. Corp. Derivative Litig., $554 \mathrm{~F}$. Supp. 2d 1044, 1066 (C.D. Cal. 2008)).

${ }^{138}$ Id. at 1144 .

${ }^{139}$ See generally Kevin LaCroix, The List: Subprime Lawsuit Dismissals and Denials, D\&O DIARY (June 10, 2008, 5:27 PM), http://www.dandodiary.com/2008/06/articles/ subprime-litigation/the-list-subprime-lawsuit-dismissals-and-denials/index.html (listing subprime and credit crisis-related suits and dispositions).

${ }^{140}$ See Brecher.v. Citigroup Inc., 797 F. Supp. 2d 354, 371 (S.D.N.Y. 2011); In re Wachovia Equity Sec. Litig., 753 F. Supp. 2d 326, 360-61 (S.D.N.Y. 2011); Brown v. Moll, No. C 09-05881 SI, 2010 WL 4704372, at *2 (N.D. Cal. Nov. 12, 2010); In re Bare Escentuals, Inc. Sec. Litig., 745 F. Supp. 2d 1052, 1077-78 (N.D. Cal. 2010); Plumbers \& Pipefitters Local Union No. 630 Pension-Annuity Trust Fund v. Arbitron Inc., 741 F. Supp. 2d 474, 490 (S.D.N.Y. 2010); In re Accuray, Inc. Sec. Litig., 757 F. Supp. 2d 936, 951 (N.D. Cal. 2010); In re Constellation Energy Grp., Inc. Sec. Litig., 738 F. Supp. 2d 614, 635 (D. Md. 2010); Plumbers \& Pipefitters Local Union 719 Pension Fund v. Zimmer Holdings, Inc., 673 F. Supp. 2d 718, 746-47 (S.D. Ind. 2009); In re Cadence Design Sys., Inc. Sec. Litig., 654 F. Supp. 2d 1037, 1049 (N.D. Cal. 2009); City of Westland Police \& Fire Ret. Sys. v. Sonic Solutions, No. C 07-05111 CW, 2009 WL 942182, at *8 (N.D. Cal. Apr. 6, 2009); Medis Investor Grp. v. Medis Techs., Ltd., 586 F. Supp. 2d 136, 146-47 (S.D.N.Y. 2008) (rejecting plaintiff's allegation because the court could not discern whether executive was senior-level); In re eSpeed, Inc. Sec. Litig., 457 F. Supp. 2d 266, 294 (S.D.N.Y. 2006); In re JP Morgan Chase Sec. Litig., 363 F. Supp. 2d 595, 628 (S.D.N.Y. 2005); In re Copper Mountain Sec. Litig., 311 F. Supp. 2d 857, 872 (N.D. Cal. 2004). 


\section{B. The Less Significant the Fact Is to the Company, the Less Indicative of Scienter and the More the Need for Particularized Allegations}

On the other end of the spectrum lie cases in which the courts insist on particularized allegations because the facts were not so material such that executives should have been aware of them. Courts push cases to this end of the spectrum by either requiring particularized allegations to bolster existing allegations that management was exposed to the facts that are the subject of the fraud, ${ }^{141}$ or by explicitly rejecting the doctrine as an end-run around the PSLRA's particularity requirement that plaintiffs allege facts with particularity. ${ }^{142}$ These courts appear to require particularized allegations to nudge the inference of scienter so that it is stronger than the nonculpable inference that senior management was unaware of those facts. ${ }^{143}$

${ }^{141}$ See S. Ferry LP, No. 2 v. Killinger, 542 F.3d 776, 785 (9th Cir. 2008); In re Daou Sys. Inc., 411 F.3d 1006, 1022 (9th Cir. 2005); PR Diamonds, Inc. v. Chandler, 364 F.3d 671, 688 (6th Cir. 2004); Rosenzweig v. Azurix Corp., 332 F.3d 854, 867 (5th Cir. 2003); see also In re Constellation Energy Grp., Inc. Sec. Litig., 738 F. Supp. 2d at 635-36; In re Huntington Bancshares Inc. Sec. Litig., 674 F. Supp. 2d 951, 970-71 (S.D. Ohio 2009); Waterford Twp. Gen. Emps. Ret. Sys. v. CompuCredit Corp., No. 1:08-CV-2270-TWT, 2009 WL 47303 15, at *7 (N.D. Ga. Dec. 4, 2009); Plumbers \& Pipefitters Local Union, 673 F. Supp. $2 \mathrm{~d}$ at $746-47$.

${ }^{142}$ See In re Wachovia Equity Sec. Litig., 753 F. Supp. 2d at 352-53 (collecting cases and discussing viability of the approach in the Second Circuit); Latham v. Matthews, $662 \mathrm{~F}$. Supp. 2d 441, 467-68 (D.S.C. 2009); In re Take-Two Interactive Sec. Litig., 551 F. Supp. 2d 247, 274 (S.D.N.Y. 2008) (refusing to find scienter based upon core operations inference because complaint lacked particularized allegations that management had access to information establishing falsity). But see Stevens v. InPhonic, Inc., 662 F. Supp. 2d 105, 121 n. 8 (D.D.C. 2009) (rejecting the core operations inference).

${ }^{143}$ See In re Wachovia Equity Sec. Litig., 753 F. Supp. 2d at 360-61 (requiring particularized allegations to support core operations theory suggesting executives knew of operational details to meet the Tellabs standard).

The Eighth Circuit has said that even if an allegation concerns the core operation of a company, the plaintiff must at a minimum allege facts that lay a foundation for an inference that the facts were known within the company. Elam v. Neidorff, 544 F.3d 921, 929-30 (8th Cir. 2008). The Eighth Circuit claims to have reserved judgment on the viability of the core operations inference, but a closer read of Elam suggests that the court has actually adopted the position that particularized allegations are required to bolster the inference of knowledge for executives. See also Cornelia I. Crowell GST Trust v. Possis Med., Inc., 519 F.3d 778, 783 (8th Cir. 2008) (The court rejected the argument that the "overarching importance" of a clinical study, which was "vital to the company's future" and that contradicted alleged statements by the company, supported an inference that senior management was "aware of its negative results" because the study was conducted independent of the company "at several off-site locations," and plaintiffs did not allege facts relating "to the executives" involvement in either its design or ongoing administration.").

On the other hand, however, in Detroit General Retirement System v. Medtronic, Inc., 621 F.3d 800 (8th Cir. 2010), the court implied that it would attribute scienter in "a situation where the falsity was so obvious that anyone familiar with the business of the company would have known the statements to be false at the time they were made." Id. at 808 . 
Routine operations that do not significantly influence the bottom line or fringe operations that are not under management's control are facts that the courts usually consider as not material enough to invoke the core operations inference. For example, allegations that senior management is aware of slight nuances in the company's daily operations usually require particularized allegations of knowledge. ${ }^{144}$ Also, in Zucco Partners, LLC v. Digimarc Corp., the Ninth Circuit held that the plaintiffs had to come forward with particularized allegations that executives were aware of or had access to information that suggested that certain statements were misleading where those statements concerned highly technical terms relating to the development process and accounting definitions. ${ }^{145}$ The court required particularized allegations because the misleading statements did not relate to "especially prominent facts," and the misrepresentations were "largely definitional [and] the falsity of the original representations would not be immediately obvious to corporate management."146 Similarly, in Glazer Capital Management, LP v. Magistri, where the alleged fraud concerned a discrete set of illegal payments by the company's foreign sales agents, the court refused to infer scienter without particularized allegations regarding the company's senior management's knowledge of the payments. ${ }^{147}$

\section{The SUPREME COURT AND THE CORE OPERATIONS INFERENCE}

The core operations inference recognizes that those in a position to know facts material to the company's core operations and its investors likely act with scienter when they make public misstatements. As explained below, the Supreme Court has provided implicit support for the core operations inference. First, those defendants encompassed by the core operations inference remain culpable actors even after the Court's most recent attempts to restrict the scope of liability under Rule 10b-5. Second, the Court said that scienter may be inferred when a defendant who is in a position to know about a statement's falsity makes a statement about a fact that the defendant should know would be material to investors. Third, the Court recognized that the lack of particularized allegations alone does not defeat a strong inference of scienter.

144 See, e.g., S. Ferry LP, No. 2, 542 F.3d at 784; Lapiner v. Camtek, Ltd., No. C 0801327 MMC, 2011 WL 445849, at *8 (N.D. Cal. Feb. 2, 2011); In re Nvidia Corp. Sec. Litig., No. 08-CV-04260-RS, 2010 WL 4117561, at*10 (N.D. Cal. Oct. 19, 2010); In re Accuray, Inc. Sec. Litig., 757 F. Supp. 2d 936, 951 (N.D. Cal. 2010).

145552 F.3d 981, 1001 (9th Cir. 2009).

146 Id.

147549 F.3d 736, 745 (9th Cir. 2008); cf. Graham v. Allis-Chalmers Mfg. Co., 188 A.2d 125,130 (Del. 1963) ("[A]bsent cause for suspicion there is no duty upon the directors to install and operate a corporate system of espionage to ferret out wrongdoing which they have no reason to suspect exists."). 


\section{A. Senior Management as Culpable Actors}

Even in light of the Supreme Court rejecting the expansion of remedies afforded to investors for securities fraud and limiting defendants' exposure to securities fraud liability, the core operations inference still fits comfortably within the Court's precedent. The Court's most recent attempts to confine the 10b-5 private right of action-Janus Capital Group, Inc. v. First Derivative Traders ${ }^{148}$ and Stoneridge Investment Partners, LLC v. Scientific-Atlanta, Inc. ${ }^{149}$-illustrate this point. ${ }^{150}$

First, in Stoneridge Investment Partners, LLC v. Scientific-Atlanta, Inc., the Supreme Court addressed the scope of scheme liability under Rule 10b-5.151 The Court held that only those upon whom investors rely may be liable under the securities laws. ${ }^{152}$ Even reading Stoneridge most narrowly, the defendants that fall under the core operations inference also fall within the zone of defendants who can be held liable after Stoneridge. Unquestionably, senior management is aware that the public statements they make will have an effect on the market price and are in fact designed to do so. 153

Similarly, even under the Supreme Court's most recent restriction of liability under Rule $10 \mathrm{~b}-5$ in Janus, ${ }^{154}$ the defendants that fall under the core operations inference are still culpable actors. In Janus, the Court held that only "the maker of a statement" may be liable under Rule 10b-5, and that a maker "is

148131 S. Ct. 2296 (2011).

149552 U.S. 148 (2008).

${ }^{150}$ Both cases were private actions. Stoneridge does not influence the scope of liability in government actions, but whether Janus does is an open question.

151552 U.S. at 152.

152 Id. at $160-67$.

153 Professor Donald C. Langevoort offers a nuanced interpretation of Stoneridge, saying that although facially the decision purports to address reliance, Stoneridge is about duty:

[S]aying that only certain kinds of actors and conduct ought to be subjected to the extraordinary risk of a fraud-on-the-market lawsuit-i.e., that the enforceable duty of candor owed specifically to all investors in the capital marketplace should be limited and should not attach to 'the whole marketplace in which the issuing company does business' unless the actors can fairly be said to owe a cognizable duty to the marketplace.

Donald C. Langevoort, Reading Stoneridge Carefully: A Duty-Based Approach to Reliance and Third Party Liability Under Rule 10b-5, 158 U. PA. L. REV. 2125, 2137 (2010) (internal quotation marks omitted). Professor Langevoort thus derives five duty-based rules for third parties, many of which focus on either those who owe a fiduciary duty to investors or those who are or should be cognizant of the effect of market fraud. Id. at 2154-55. We express no view about these rules for liability for third parties or the core operations inference's application in that context. We briefly note, however, that the core operations inference might prove useful if, for example, an accountant lies about accounting practices, which is the accountant's core operation.

154131 S. Ct. 2296 (2011). 
the person or entity with ultimate authority over the statement, including its content and whether and how to communicate it."155 Senior management are "makers" of public misstatements concerning core operations. The Court emphasized that those with "control" over the content and dissemination of public statements fall within the purview of Rule 10b-5,156 and the board of directors (or senior management under the core operations inference) is typically the entity that is charged with "ultimate authority" over the business. ${ }^{157}$ Moreover, some federal courts recognized before Janus that an officer who signs an SEC filing "makes" a statement under Section 10(b) and Rule 10b-5. ${ }^{158}$ Janus also focused on the person or entity with control over the statement that ultimately makes its way into the market, reinforcing the idea that those who understand the severity of misleading information in the marketplace likewise should be subject to liability.

\section{B. Materiality as a Basis to Infer Scienter}

Materiality is the crux of the core operations inference, and the Supreme Court's decisions in Merck \& Co. v. Reynolds ${ }^{159}$ and Matrixx Initiatives, Inc. $v$. Siracusano ${ }^{160}$ provide more specific support for the core operations inference. In Merck and Matrixx, the Court recognized that scienter may be inferred if a defendant who is in a certain position acts recklessly when he makes misleading statements about facts that he should know are material to investors. ${ }^{161}$ This, in essence, is the core operations inference: we can infer scienter when senior management makes misleading statements about core operations-facts that are material to the company and to its investors.

155 Id. at 2302 .

156 See id.

157 See DEL. CODE ANN. tit. 8, § 141(a) (2001) (stating that the board of directors has authority over the company).

158 See, e.g., Howard v. Everex Sys., Inc., 228 F.3d 1057, 1061 (9th Cir. 2000); W. Palm Beach Firefighters' Pension Fund v. Startek, Inc., No. 05-cv-01265-WDM-MEH, 2008 WL 879023, at *14 (D. Colo. Mar. 28, 2008); In re Reliance Sec. Litig., 135 F. Supp. 2d 480, 503 (D. Del. 2001). See generally Lisa M. Fairfax, Form over Substance?: Officer Certification and the Promise of Enhanced Personal Accountability Under the SarbanesOxley Act, 55 RuTGERS L. Rev. 1 (2002). But see, e.g., In re Royal Ahold N.V. Sec. \& ERISA Litig., 351 F. Supp. 2d 334, 385 (D. Md. 2004) (dismissing Section 10(b) and Rule $10 \mathrm{~b}-5$ claims against the company's CEO because plaintiffs alleged "very little" other than the fact that he signed SEC filings).

We note that those who sign false filings with the SEC are likely liable, not only under Section $10(\mathrm{~b})$ and Rule $10 \mathrm{~b}-5$ as primary violators, but also under Section 18 of the 1934 Act. See 15 U.S.C. § $78 \mathrm{r}(\mathrm{a})(2006)$.

159130 S. Ct. 1784 (2010).

160131 S. Ct. 1309 (2011).

161 Id. at 1324; Merck, 130 S. Ct. at 1796. 
In Merck \& Co., the Court stated that "certain statements are such that, to show them false is normally to show scienter as well."162 The Court then provided an example: "It is unlikely ... that someone would falsely say 'I am not married' without being aware of the fact that his statement is false."163 From this statement, one may conclude that scienter can be inferred when a defendant makes misstatements about matters that his position suggests that he should know.

Likewise, in Matrixx, the Court concluded that executives acted with scienter when they made false statements concerning its "leading," "core brand" of product. ${ }^{164}$ There, the plaintiffs alleged that a pharmaceutical company and three of its executives made misleading statements about a cold remedy. ${ }^{165}$ The defendants defended on the basis that, although the statements may have been misleading, they were not materially so because the defendants did not know of a statistically significant number of adverse events involving the cold remedy. ${ }^{166}$ The Court rejected this bright-line rule of materiality and concluded that the misleading statements were material. ${ }^{167}$ Once the Court concluded the facts were material, inferring scienter was easy: the Court assumed recklessness was sufficient and rejected the defendants' defense that they lacked scienter because they did not know the facts were material. ${ }^{168}$ Although the Court's actual discussion of scienter is less than informative, implicit in the Court's conclusion is that the defendant's defense wouldn't fly because, in the Court's view, the defendants should have known the facts would have been material. In other words, whether the defendant was correct about the materiality of a fact was largely irrelevant-executives should have known facts that are material to investors.

What Merck and Matrixx tell us is that when it comes to inferring scienter, position and materiality matter. If the defendant is in a position such that he should know the truth of a statement (if he is married, he should know it), then on a motion to dismiss we may infer scienter from the gravity of a false statement alone. In other words, if the defendant makes misleading statements of facts material to investors as core operations likely will be, then the defendant is acting recklessly.

162 Merck, 130 S. Ct. at 1796.

163 Id. at 1797.

164 Matrixx, 131 S. Ct. at $1313-14,1324-25$.

165 Id. at 1314.

166 Id. at 1324.

${ }^{167} \mathrm{Id}$. at 1322 .

${ }^{168}$ Id. at 1324-25. The Sixth Circuit, discussing Matrixx's analysis of scienter, observed: "[T] he Court provided for us a post-Tellabs example of how to consider scienter pleadings holistically in section $10(\mathrm{~b})$ cases. Writing for the Court, Justice Sotomayor expertly addressed the allegations collectively, did so quickly, and, importantly, did not parse out the allegations for individual analysis." Frank v. Dana Corp., 647 F.3d 954, 961 (6th Cir. 2011) (citations omitted). 


\section{Subsuming the Particularity Requirement}

The particularity requirement often stands in the way of inferring scienter from misstatements about the company's core operations, but it shouldn't. The last pillar that supports the core operations inference is the Supreme Court's containment of the particularity requirement. The core operations inference, by assuming executives were aware of facts pertaining to the company's core operations, obviates the need for plaintiffs to provide particularized allegations that senior management knew of or had access to the facts that were the subject of the fraud. ${ }^{169}$ This Part shows that Tellabs softens the PSLRA's particularity requirement, saying that whether an allegation is particularized simply factors into the holistic scienter analysis.

Several federal courts have held that the core operations inference alone is insufficient to satisfy the pleading standards under the PSLRA because the plaintiffs have not provided particularized allegations that detail senior management's actual knowledge. ${ }^{170}$ Rather, according to these courts, the core operations inference only bolsters the strength of an inference of scienter when plaintiffs have already alleged particularized facts indicating that the defendants knew or might have known their statements were false. ${ }^{171}$

For example, in In re Read-Rite Corp., 172 the investors sued a company that made components for hard-disk drives and the company's CEO and COO, alleging that the defendants made misstatements regarding the demand of its products from one of its four largest customers. ${ }^{173}$ The Ninth Circuit acknowledged that although one could reasonably infer that the CEO and COO were aware of the false statements about demand for the company's products because of their job duties, a "reasonable inference" does not satisfy the PSLRA requirement that the plaintiffs plead facts with particularity. ${ }^{174}$ The Ninth Circuit also addressed Epstein v. Itron, Inc., ${ }^{175}$ a district court case decided before the Ninth Circuit interpreted the PSLRA in In re Silicon Graphics Inc. Securities Litigation. ${ }^{176}$ In Epstein, the court held that facts critical to a company's core operations or an important transaction generally are so apparent

169 See, e.g., Stevens v. InPhonic, Inc., 662 F. Supp. 2d 105, 121 n.8 (D.D.C. 2009).

170 See, e.g., In re Bally Total Fitness Sec. Litig., No. 04 C 3530, 2006 WL 3714708, at *9 (N.D. Ill. July 12, 2006); see also Gregory A. Markel \& Martin L. Seidel, 'Core Operations' Doctrine May Undermine PSLRA, N.Y. L.J., Apr. 29, 2010, at 5.

171 See, e.g., Glaser v. The9, Ltd., 772 F. Supp. 2d 573 (S.D.N.Y. 2011); In re Reserve Fund Sec. \& Derivative Litig., 732 F. Supp. 2d 310, 322-23 (S.D.N.Y. 2010); Glover v. DeLuca, No. 2:03-CV-0288, 2006 WL 2850448, at *9 (W.D. Pa. Sept. 29, 2006).

172 In re Read-Rite Corp., 335 F.3d 843 (9th Cir. 2003).

$173 \mathrm{Id}$. at $844-45$.

174 Id. at $848-49$.

175993 F. Supp. 1314 (E.D. Wash. 1998). This decision is recognized as the first to refer to the core operations inference of scienter. Jared L. Kopel \& Maulik Shah, The Core Operations Inference, 44 REV. SEC. \& COMMODITIES REG. 113, 114 n.5 (2011).

176183 F.3d 970 (9th Cir.1999). 
that knowledge may be attributed to the company and its key officers. ${ }^{177}$ But in Read-Rite, the court held that this rule was no longer the law as it contravened the PSLRA, which "plainly requires the plaintiff to plead 'particular facts in the complaint' that "raise a "strong inference" that misleading statements were knowingly or [with] deliberate recklessness made to investors.",178

Not all courts agreed with this approach, however, and many implicitly recognized that the core operations inference alone is sufficient to overcome the particularity requirement. ${ }^{179}$ For instance, one court highlighted "two commonsense principles" that endured the PSLRA:

First, the closer a situation is to a business's core operations, the more reasonable it may be to infer that senior management is aware of the situation. Second, the more pervasive and widespread a fraudulent scheme is within a company, the more reasonable it may be to infer that senior executives were aware of the scheme. ${ }^{180}$

But we need not look to only the federal appellate and district courts. The Supreme Court in Tellabs provided considerable - and somewhat neglectedguidance on this question. In Tellabs, the Court lessened the force of the particularity requirement to just one factor to evaluate in a holistic assessment. For example, the majority in Tellabs stated that "omissions and ambiguities count against inferring scienter, for plaintiffs must 'state with particularity facts giving rise to a strong inference that the defendant acted with the required state of mind." "181 But, the Court continued, this was just one aspect to take into account in the district judge's collective assessment of the complaint. ${ }^{182}$ The majority's opinion cannot be read as holding that vague allegations do not enter the scienter assessment altogether. Indeed, this was the very point of Justice Alito's concurrence, where the Justice argued that allegations that did not meet the particularity requirement should not enter the scienter analysis at all. ${ }^{183}$

${ }^{177}$ Epstein, 993 F. Supp. at 1326.

178 In re Read-Rite Corp., 335 F.3d at 848 (quoting Ronconi v. Larkin, 253 F.3d, 423, 429 (9th Cir. 2001)).

${ }^{179}$ See, e.g., Crowell v. Ionics, Inc., 343 F. Supp. 2d 1, 19 (D. Mass. 2004); In re Sears, Roebuck \& Co. Sec. Litig., 291 F. Supp. 2d 722, 727 (N.D. Ill. 2003); In re Ramp Networks, Inc. Sec. Litig., 201 F. Supp. 2d 1051, 1076 (N.D. Cal. 2002); In re Xerox Corp. Sec. Litig., 165 F. Supp. 2d 208, 223 (D. Conn. 2001).

${ }^{180}$ City of Austin Police Ret. Sys. v. ITT Educ. Servs., Inc., 388 F. Supp. 2d 932, 949 (S.D. Ind. 2005) (citation omitted).

181 Tellabs, Inc. v. Makor Issues \& Rights, Ltd., 551 U.S. 308, 326 (2007) (citing 15 U.S.C. $\S 78 \mathrm{u}-4(\mathrm{~b})(2)(2006))$.

182 Id. Interestingly, the Ninth Circuit has said that Tellabs did not alter the particularity requirement, but then the court has gone on to note that the particularity requirement is now incorporated into a holistic assessment of the facts of the complaint. Zucco Partners, LLC v. Digimarc Corp., 552 F.3d 981, 987 (9th Cir. 2009).

${ }^{183}$ Tellabs, 551 U.S. at 334 (Alito, J., concurring) (stating that the majority's approach "contradict[s] the clear statutory language,"... "undermines the particularity requirement's purpose of preventing a plaintiff from using vague or general allegations in order to get by a 
What Tellabs means for the core operations inference is that the vagueness surrounding precisely how senior management knew about the facts pertaining to the misleading statements is simply one factor to consider in the scienter analysis. This is similar to how courts should treat allegations from confidential witnesses: that the allegation comes from an unnamed source may weigh against scienter, but it does not require a steep discount of the allegation solely because of this ambiguity. ${ }^{184}$ Under Tellabs's construct, the particularity of an allegation may suggest a higher probability that the defendant acted with scienter, but the lack of particularity does not negate a strong inference of scienter altogether.

\section{CONCLUSION}

Inferring state of mind from mental markers is a messy endeavor. But where senior management makes misleading statements regarding matters within their company's core operations, one can strongly infer that the defendant acted with scienter as defined by the securities laws. This core operations inference of scienter plays an important role in private securities fraud litigation, though it is often downplayed as too conclusory. Properly understood, however, the inference is grounded in common sense, the securities laws, and Supreme Court jurisprudence. The inference enables plaintiffs to satisfy the PSLRA's heightened pleading burden and it promotes recovery for injured investors.

motion to dismiss for failure to state a claim," and "[strips] [t]he particularity requirement ... of all meaning").

184 See Michael J. Kaufman \& John M. Wunderlich, Congress, the Supreme Court and the Proper Role of Confidential Informants in Securities Fraud Litigation, 36 SEC. REG. L.J. 345, 352 (2008); Gideon Mark, Confidential Witnesses in Securities Litigation, 36 J. CoRP. L. 551, 569-604 (2011); see also S. Ferry LP, No. 2 v. Killinger, 542 F.3d 776, 784 (9th Cir. 2008) ("In Tellabs, the Court explained that 'omissions and ambiguities count against inferring scienter,' but held that they were still properly considered."). But see Higginbotham v. Baxter Int'l, Inc., 495 F.3d 753, 757 (7th Cir. 2007) (steeply discounting allegations from confidential witnesses). 